Article

\title{
Identification of Economic Activity in a Bronze Age Settlement in Central Russia Based on the Results of XRF Analysis of Samples of the Cultural Layer
}

\author{
Konstantin Voronin (1) \\ Institute of Archaeology, Russian Academy of Sciences, 19 Dm. Uljanova St, 117292 Moscow, Russia; \\ volter1707@gmail.com
}

Received: 22 June 2020; Accepted: 29 June 2020; Published: 6 July 2020

\begin{abstract}
In central Russia, the examination of characteristics of economic activity of Bronze Age settlements and the determination of functional zones that existed in their territories in the first half of the second millennium BC based on the results of XRF (X-ray Fluorescence) analysis of samples of the cultural layer have never been done before. The data from elemental analysis of the samples of the cultural layer of the Bronze Age settlement Pesochnoe 1 from an excavation area of $126 \mathrm{~m}^{2}$ obtained via the XRF method showed significant content of copper $(\mathrm{Cu})$, zinc $(\mathrm{Zn})$, calcium $(\mathrm{Ca})$ and phosphorus $(\mathrm{P})$, several times exceeding the content of the same chemical elements in the surrounding soils. The discovered $\mathrm{Cu}$ can be associated with metalworking, $\mathrm{Zn}$ are likely from ash and the biomass of the aquatic environment, and $\mathrm{Ca}$ and $\mathrm{P}$ can be found in bone remnants. Analysis of the spatial distribution of archaeological objects with quantitative indicators of $\mathrm{Cu}, \mathrm{Zn}, \mathrm{Ca}, \mathrm{P}$ made it possible to distinguish two functional areas in the excavation of the Bronze Age settlement. A very high concentration of $\mathrm{Cu}, \mathrm{Zn}, \mathrm{Ca}, \mathrm{P}$ recorded in the first functional zone, in the center of which was a hearth, indicates diverse activity that took place in this territory, including the use of different organic materials (plants, bones) as fuel and melting of metal. The second functional area with high concentrations of $\mathrm{Zn}, \mathrm{Ca}$ and especially $\mathrm{P}$ suggests it was a place where biomaterials of animal origin might have been used.
\end{abstract}

Keywords: central Russia; geoarchaeology; Bronze Age; settlement; textile ceramic culture; XRF; copper; zinc; calcium; phosphorus

\section{Introduction}

It is quite a difficult task to characterize economic activity in Bronze Age settlements in the central part of Russia. It poses a lot of questions due to the fact that the complexes of ancient settlements contain only a part of antique objects used in everyday life. Most often archaeological complexes of settlements of the second millennium BC in the territory between the Volga and Oka rivers in their interfluve uncover ceramics and stone tools. Archaeological finds made of metal and organic materials are extremely rare. Metal objects were considered of extreme value in the Bronze Age, and were imported into the territory of modern central Russia. Objects of organic origin are even less common because geochemical conditions of the cultural layer usually prevent their conservation. As a result, analysis of objects found in those settlements can only provide fragmentary information about the economic activity that actually took place in a given territory. To provide a comprehensive overview on this matter, works on physical-chemical identification and explorations of cultural layers of ancient settlements can present a great interest. Some studies show that the chemical elements contained in cultural layers of settlements, soil layers of zones of economic development and soil layers of the territories of ancient industries prove to be an informative source of the types of economic activity that 
existed in them [1-9]. In the Bronze Age settlements in central Russia, such work potentially allows to record traces of various types of economic activity and to distinguish different functional zones in the investigated territory, all through the utilization of geo-chemical markers, i.e., the chemical elements contained in the cultural layer. These data, combined with the studies of the artifacts themselves, natural scientific information on the chronology of Bronze Age cultures and the accompanying data on the climatic and landscape conditions, together form an extensive multifaceted source on the history of archaeological cultures of the Volga-Oka basin in the second millennium BC. The purpose of this work is to characterize economic activity of the settlement Pesochnoe 1 and to determine the functional zones that existed there in the first half of the second millennium BC based on the results of XRF analysis of samples of the cultural layer of the Bronze Age.

\section{Object of the Research}

\subsection{Characteristics of the Settlement Pesochnoe 1}

The Pesochnoe 1 settlement (Figure 1), located in the Rostov district of Yaroslavl region in the basin of Lake Nero, $2 \mathrm{~km}$ south of Rostov the Great, can serve as an example of such analysis. This ancient settlement was situated toward the southern headland of the delta of the small river Ishnya on the first mid-Holocene lake terrace, at a height of about $97 \mathrm{~m}$ according to the Baltic altitude system. It stretches for about $94 \mathrm{~m}$ from the northwest to the southeast along the ancient bank of the river. In 2008, during an archaeological research at the settlement of Pesochnoe 1 in excavation No.3 in an area of $126 \mathrm{~m}^{2}$ across the entire thickness of the cultural layer right up to the level of mainland, features of the Bronze Age were encountered: hearth No.1 (Figures 2 and 3), accumulations of stones, utility pits and postholes (Figure 2). These objects of the Bronze Age were accompanied by artifacts associated with the Bronze Age cultures of the Volga-Oka interfluve-the Chirkov culture ( 2000 BC- 1500 BC) (25-29 in Figure 4) and the textile ceramic culture ( 2000 BC- 1500 BC) (1-24,30 in Figure 4), among which the textile ceramics artifacts predominated $[10,11]$. Clay products of the textile ceramic culture were represented by two round-bottom vessels (30 in Figure 4) with textile ornaments made of clay mass with a mineral admixture. Additionally, 1342 fragments of ceramic vessels (22-24 in Figure 4) and 8 clay weights were discovered (6,7 in Figure 4). Among the findings there were scrapers (92 specimens) $(8,9,11$ in Figure 4), arrowheads and darts points (75 specimens) (1-5 in Figure 4$)$ in the set of stone objects, which predominated quantitatively; among other types of tools there were single pieces of flint cutting tools (10,12,13 in Figure 4), shale chisels and mortice chisels present (14,16 in Figure 4). Among metal tools, a fragment of a copper plate tool (possibly a broken ax blade) was discovered (19 in Figure 4). The metalwork traces are represented by 11 metal splashes from crucibles $(20,21$ in Figure 4), and fragments of crucibles (15,17 in Figure 4) [12]. 

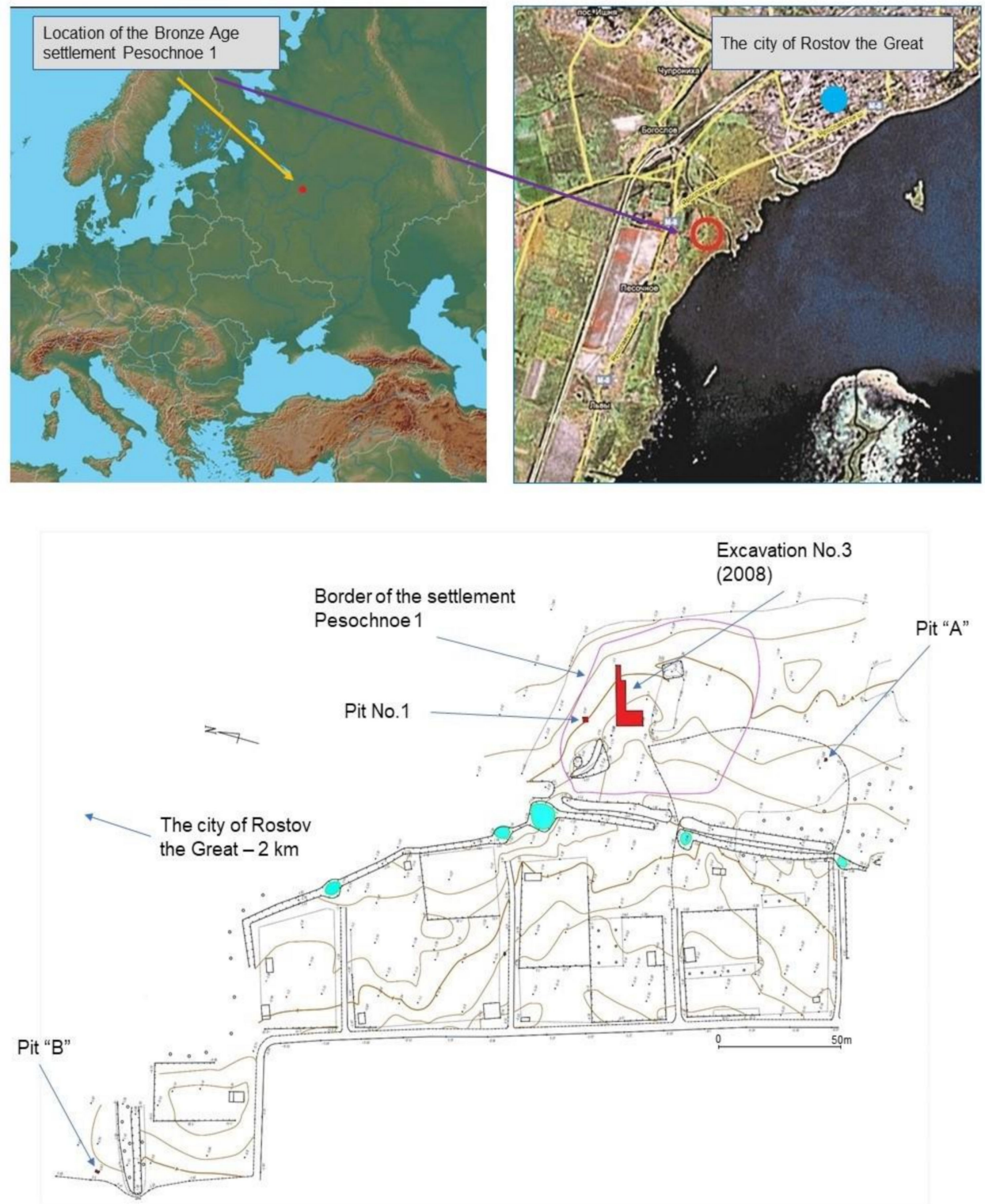

Figure 1. Bronze Age settlement Pesochnoe 1. Location of the archaeological site on a satellite image and on a topographic plan. 


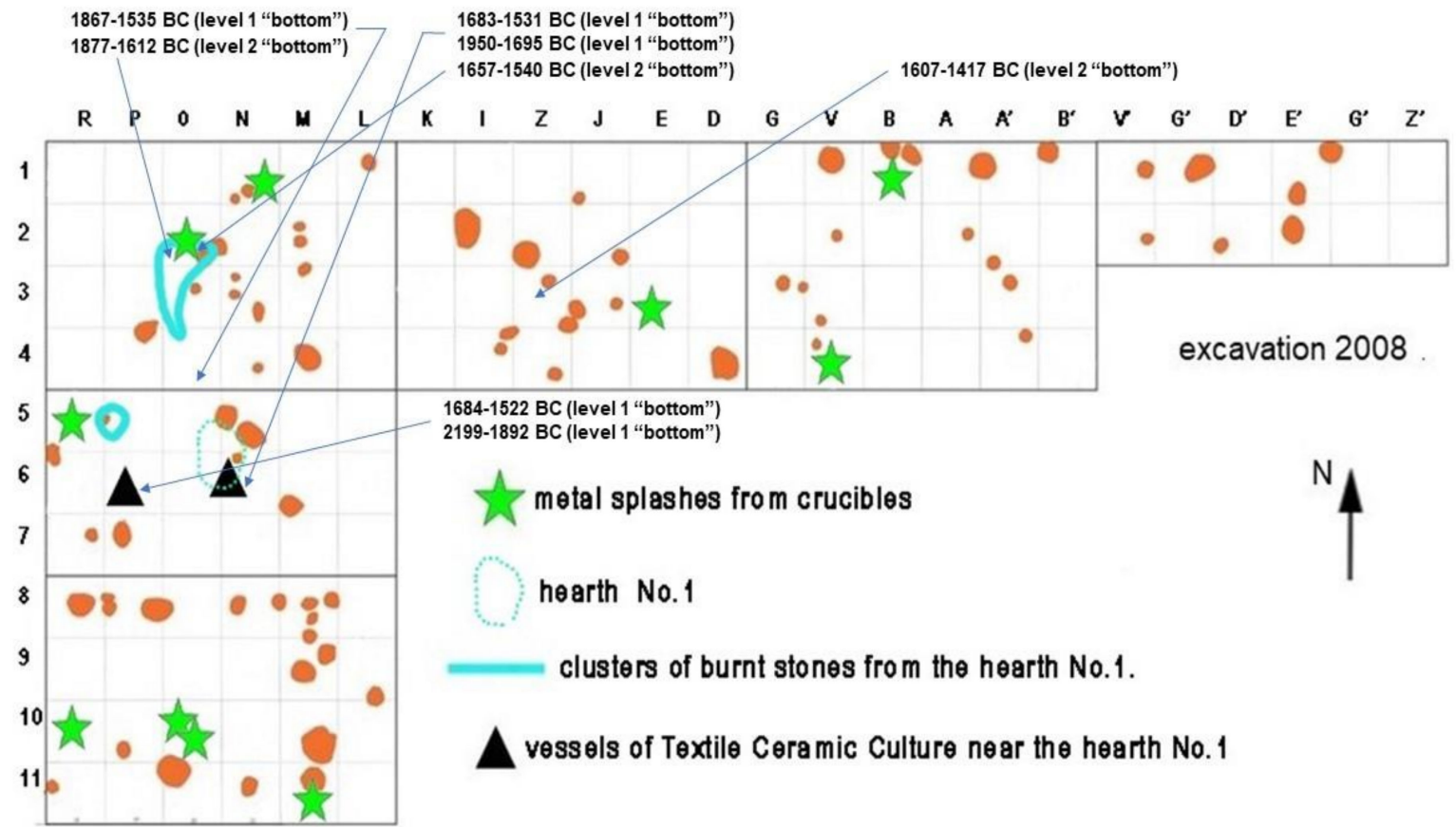

Figure 2. The Pesochnoe 1 settlement. Location of the objects of the Bronze Age in excavation No.3 (2008): postholes, hearth No.1, clusters of burnt stones from hearth No.1, vessels of the textile ceramic culture, metal splashes from crucibles.

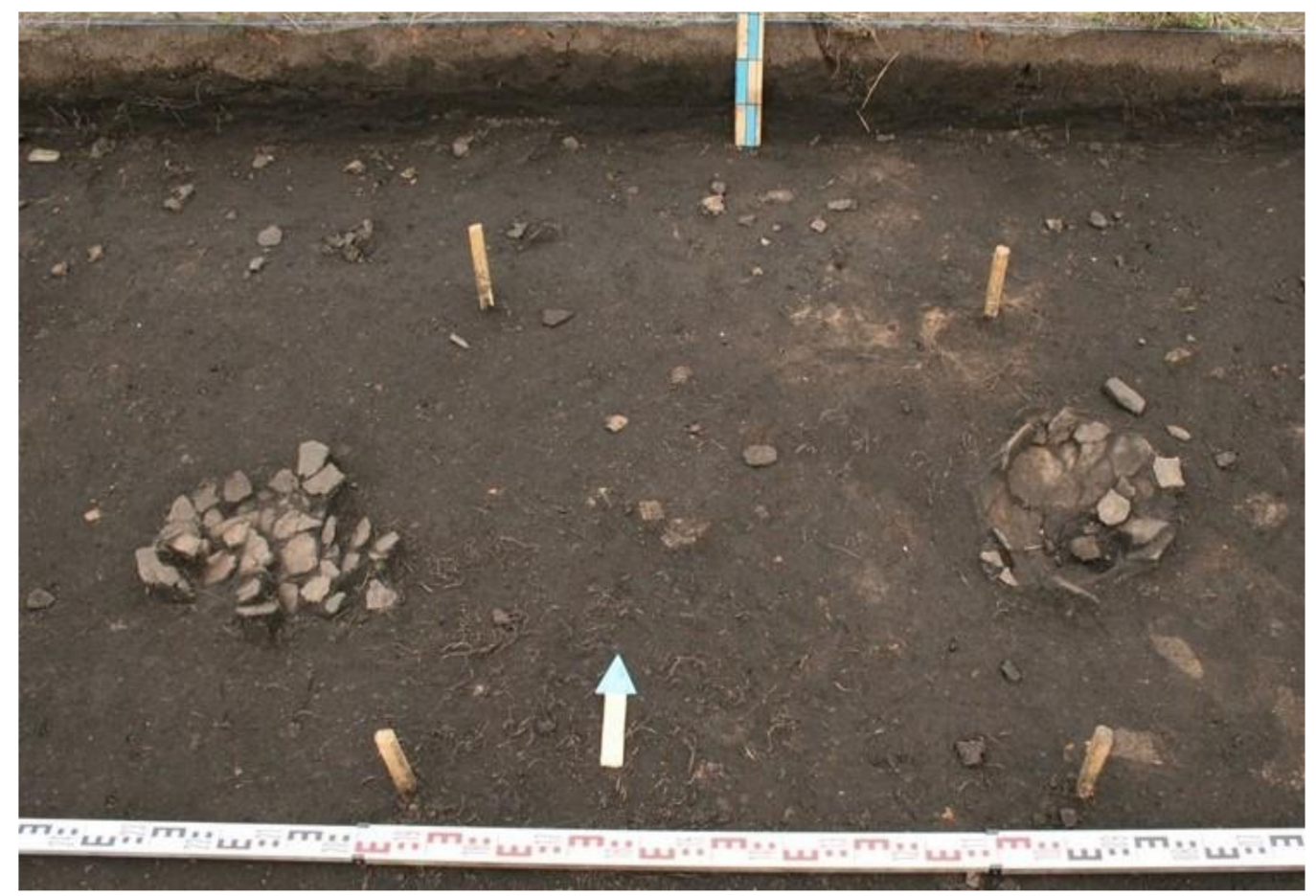

Figure 3. The Pesochnoe 1 settlement. Excavation No. 3 (2008), squares N-6, O-6, P-6. Location of hearth No.1 and two vessels of textile ceramic culture. View from the south. 


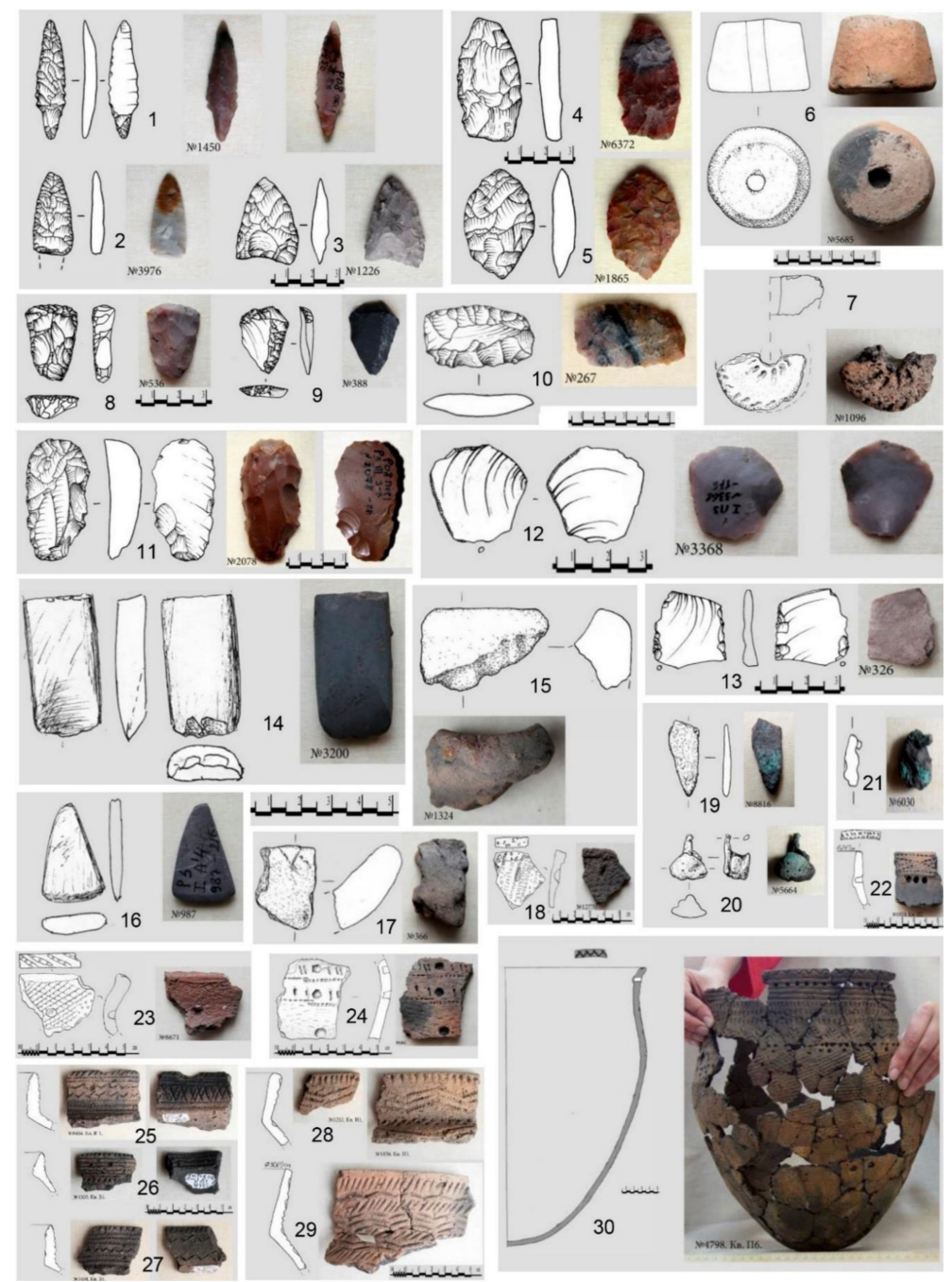

Figure 4. Bronze Age items found in the excavation. Flint arrowheads-1-3; flint dart tips-4,5; flint scrapers - 8,9,11; flint cutting tools-10,12,13; shale chisels and mortice chisels-14,16; fragments of crucibles-15,17; a fragment of a copper tool-19; metal splashes from crucibles-20,21; clay weights $-6,7$; ceramics of the Chirkov culture ( 2000 BC- 1500 BC) -25-29; ceramics of the textile ceramic culture $(\sim 2000 \mathrm{BC}-\sim 1500 \mathrm{BC})-22-24,30$.

\subsection{Characteristics of the Cultural Layer of the Pesochnoe 1 Settlement}

A homogeneous, barely differentiated cultural layer of the Pesochnoe 1 settlement $[13,14]$ with an average thickness of about $35 \mathrm{~cm}$ (Figure $5 \mathrm{a}$ ) is covered by alluvial deposits and sterile brown peat with a thickness of 15-20 cm. Its substance is a dark-brown, homogeneously light, rarely medium in density clay loam with a high content of sand fractions, has inclusions of coal and a large quantity of finely-dispersed calcined bone [15].The content of this in some samples, taken for soil chemical analysis, reached $10 \%$ of the amount of selected soil (Figure 5b). In the studied area of 2008 (excavation No.3), the cultural layer of the Pesochnoe 1 settlement is highly similar to the mid-Holocene dark-colored paleosols of the Lake Nero region, a distinctive feature of which is the high content of the second fraction of humic acids [16] similar to chernozems and forest soils common in forest-steppe areas [13]. Consequently, in the mid-Holocene period ( $5800 \mathrm{BC}-\sim 700 \mathrm{BC})$, the end of which coincides with the Bronze Age, climatic conditions, simultaneous to the period of existence of the Pesochnoe 1 settlement ( 2000 BC- 1500 BC), determined by a series of 18 radiocarbon dates [17], some of which are presented in Figures 2 and $5 \mathrm{a}$, were drier and warmer than the modern ones: the settlement was surrounded by broad-leaved forest and forest-steppe landscapes. According to the results of a palynological 
analysis, the vegetation list in the vicinity of the settlement of Pesochnoe 1 was represented by birch, alder and spruce trees alongside broad-leaved species and an insignificant share of pine trees [18]. The laboratory of the Institute of Environmental Geochemistry of the National Academy of Sciences of Ukraine [17] carried out a radiocarbon dating of the cultural layer based on its humus using a method of liquid scintillation. The results of the study indicate that the formation of the cultural layer of the Bronze Age of the Pesochnoe 1 settlement took place in the mid-Holocene in the first half of the second millennium BC and had ended no later than the middle of the second millennium BC (Figures 2 and $5 a$ ). Respectively, the objects and artifacts date back to the period no later than that time (Figures 2-4). During this climatic period, as a result of global Euro-Asian aridization, elements of the steppe and forest-steppe landscape spread deep into the forest zone of central Russia. In this territory, two peaks of warming which took place around 2000-1800 and about 1400 BC were noted. The emergence of new landscapes and climate warming created favorable natural conditions for the penetration of elements of the steppe-forest-steppe cultural traditions and (or) the import of new economic activities and technologies into the cultures of the population of the forest zone [12].

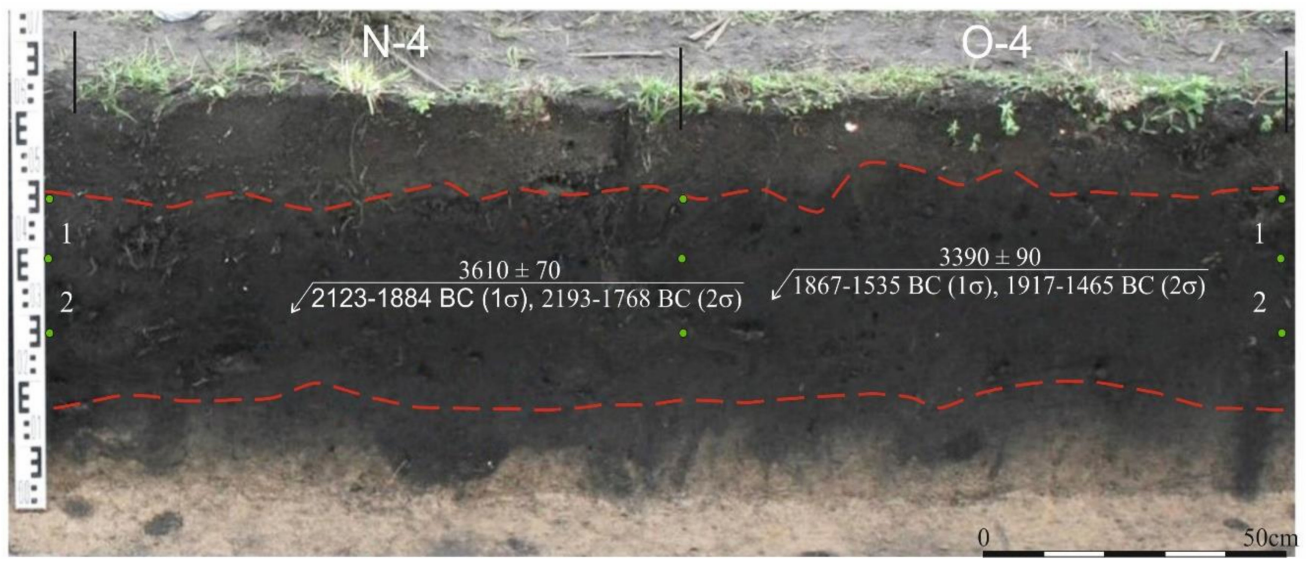

(a)

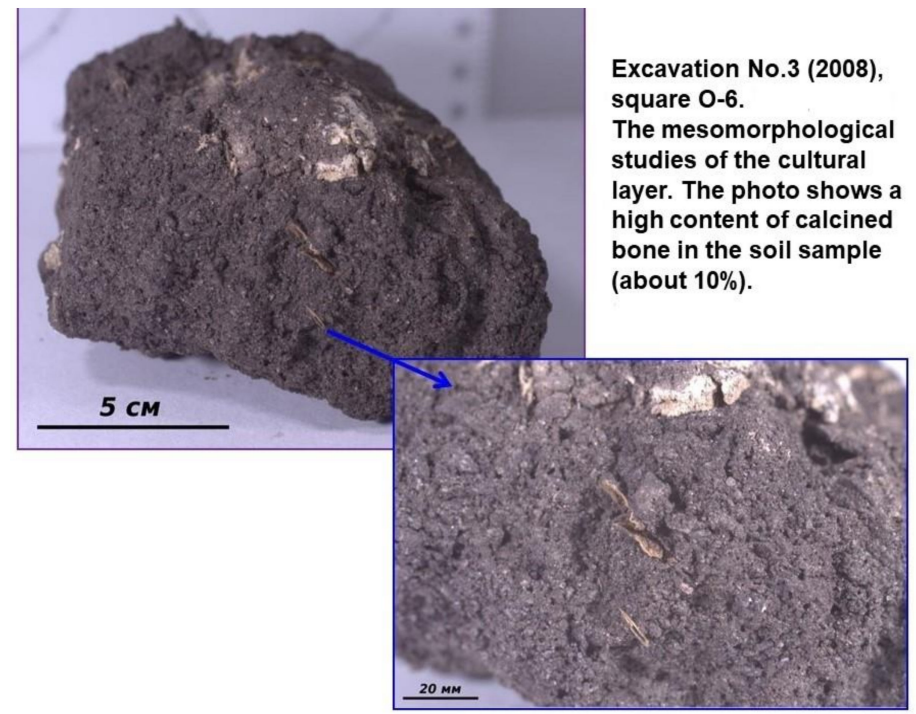

(b)

Figure 5. The Pesochnoe 1 settlement; (a) the cultural layer and its radiocarbon dates: the cultural layer of dark gray to black, loamy, with a volume of 30-40 cm, covered by a layer of alluvium of $15-20 \mathrm{~cm}$, the zone bounded by a red dotted lines is the cultural layer of the Bronze Age, the levels marked with green dots are arbitrary strata 1 and 2; (b) the mesomorphological studies of the cultural layer. 


\section{Materials and Methods}

Excavation No.3 (2008) was divided into a grid of squares $1 \mathrm{~m} \times 1 \mathrm{~m}$ (Figure 2) and the cultural layer was dissected by trowels, knives and scoops. Graphic, photographic and spatial instrumental fixation of the found objects was carried out inside the arbitrary strata, with a thickness of 10-12 cm.

At the same time, samples of the cultural layer were extracted for laboratory research within the boundaries of the arbitrary strata of the excavation. They were taken sequentially from each square taking into account changes in the soil structure-for example, if two different lithological formations were found in a square of the excavation, then two samples were taken for analysis. In excavation No.3 in the area of $126 \mathrm{~m}^{2}, 383$ samples of the cultural layer of the Bronze Age were found. Studies of the samples of the cultural layer included fractional determination of humus composition from the cultural layer. Humus allowed the radiocarbon liquid scintillation dating. Tree types were determined by the pieces of coal contained in the cultural layer, and palynological studies were carried out. XRD analysis (X-ray diffractometer ARL X'TRA, Cu anode, Thermo Scientific, Switzerland) of 5 samples of the cultural layer from hearth No.1 (Figures 2 and 3), located in squares N-5, N-6, O-5, O-6 of excavation No.3, was performed. Twelve metal artifacts were examined by $\mathrm{X}$-ray fluorescence (XRF) and Scanning electron microscopy and energy dispersive X-ray spectroscopy (SEM/EDS) analysis (FEI Quanta 3D 200i scanning electron microscope, Eindhoven, The Netherlands). Elemental composition of the samples of the cultural layer was determined by XRF analysis.

The results of XRF analysis samples of the cultural layer of the Bronze Age, selected at the settlement of Pesochnoe 1 from excavation No.3 and pit No.1, are presented and interpreted in this work in the context of the stated objectives. A total of 350 samples of the cultural layer were examined by the XRF method. They were collected across the entire area of the excavation at three different depths within two arbitrary strata with a thickness of 10-12 cm: the first ( 1 "top", 1 "bottom") and the second ( 2 "bottom"). Elemental composition of the samples of the cultural layer was analyzed in the Laboratory of Mineral Substances Analysis of the Institute of Geology of Ore Deposits, Petrography, Mineralogy and Geochemistry of the Russian Academy of Sciences (IGEM RAS). An automatic sequential wavelength dispersive X-ray fluorescence spectrometer PW 2400 (Philips) with analytical software SuperQ, PANalytical 2009 was used in the work (manufacturer-Philips Analytical X-ray B. V., Lelyweg 1, 7602 Ea Almelo, The Netherlands). The spectrometer is designed to determine the mass concentration of chemical elements in solid and liquid environments, powders and films. The spectral range of the device is $6.7-0.091 \mathrm{~nm}$. The range of analyzed elements is Be (4) up to $\mathrm{U}(92)$, the detection limits of elements are $10^{-4}-10^{-2}$. The device is equipped with a super sharp end window X-ray tube $(60 \mathrm{kV}, 125 \mathrm{~mA}, 3000 \mathrm{~W}$ max., Rhodium anode). Hight tension (HT) generator: high frequency (ultrasonic), microprocessor controlled, $60 \mathrm{kV}, 125 \mathrm{~mA}, 3000 \mathrm{~W}$ max., $0.0005 \%$ stability. The measurements were carried out at a voltage of $10 \mathrm{kV}-50 \mathrm{kV}$. The accuracy of the measurements is $5 \mathrm{ppm}$. Due to the presence of humic acids in the 2nd fraction, the cultural layer of the Pesochnoe 1 settlement is structurally similar to chernozem soils. Therefore, for the XRF analysis, the device was calibrated for the content of trace elements in soils using certified standard material of Russian soils SP-2 "Chernozems".

For laboratory studies, samples of the cultural layer weighing about $2 \mathrm{~kg}$ were placed in clean plastic bags using steel tools and were then hermetically packed. Then, in a clean room, protected from dust and other contaminants, the remnants of modern plant debris were eliminated from the samples and the selected samples of the cultural layer were dried. Samples were taken from the dried masses of the cultural layer for XRF analysis, were thoroughly crushed and sieved through a $1 \mathrm{~mm} \times 1 \mathrm{~mm}$ mesh nylon sieve, and then mechanically grinded up into a finer fraction to obtain particles about $50 \mu \mathrm{m}$ in size. Subsequently, to reduce the matrix effect during the analysis, a powder sample was fused at a temperature of $1100-1200^{\circ} \mathrm{C}$. 


\section{Results}

\subsection{The Results of the XRF Analysis of Samples of the Cultural Layer}

An elemental analysis by the XRF method was performed for 350 samples of the cultural layer of the Bronze Age of the Pesochnoe 1 settlement. Of the 350 samples of the cultural layer of the Bronze Age studied by the XRF method, 349 samples came from excavation No.3 and one sample from pit No.1, located $12 \mathrm{~m}$ north of the excavation No.3. The main focus of the study was on the samples of the cultural layer from excavation No.3. A sample of the cultural layer from pit No.1 was studied in order to understand the uniformity of the concentration of chemical elements in the cultural layer of the Bronze Age of the Pesochnoe 1 settlement. In excavation No.3, samples were taken from the two upper arbitrary strata of the cultural layer, the radiocarbon age of which were $3610 \pm 70 / 1 \sigma 2123-1884 \mathrm{BC}$,

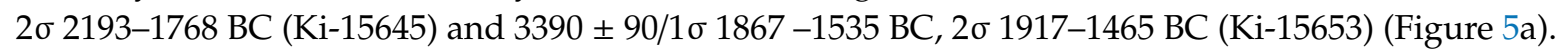
The total thickness of the two arbitrary strata was 20-24 cm. Differences in the lithological structure of the cultural layer were observed only at the location of hearth No.1 (Figures 2 and 3), located in squares N-5, N-6, O-5, O-6 of Excavation No.3. Since the cultural layer of the Pesochnoe 1 settlement has a uniformly dark color (Figure 5a), the soil samples taken from it were visually the same. However, unlike other samples of the cultural layer of the Bronze Age from excavation No.3, samples from hearth No. 1 contained calcined bones up to $1 \mathrm{~cm}^{2}$ in size. (Figure 5b), while in all other samples, calcined bone was found in a finely dispersed form.

During the study of samples of the cultural layer of the Bronze Age of the Pesochnoe 1 settlement, one sample of soils from pits located in the vicinity of the ancient Pesochnoe 1 settlement was taken for a comparative background study by XRF analysis (Figure 1). Pit "A" (background soil collection spot near the settlement) is located $82 \mathrm{~m}$ south of excavation No.3 on the same slope of the first mid-Holocene lake terrace as Pesochnoe 1. The background soil recorded at depths of 34-39 cm was grey-brownish clay loam with a thickness of about $5 \mathrm{~cm}$ and a radiocarbon age of

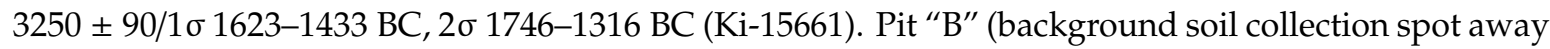
from the settlement) is located $209 \mathrm{~m}$ northwest of excavation No.3 on the elevation of the relief of the first mid-Holocene lake terrace. The background soil, recorded at depth of 32-45 cm, was a grey-greyish-brown condensed clay loam with a thickness of about $13 \mathrm{~cm}$ and a radiocarbon age of

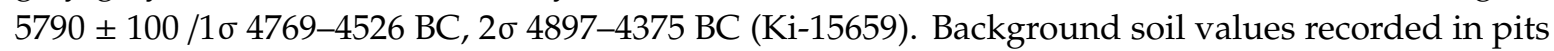
" $\mathrm{A}$ " and " $\mathrm{B}$ " refer to the dark-colored humus horizons that were formed in the region of Lake Nero in the mid-Holocene ( 5800 BC- 700 BC) [19]. Unlike the cultural layer of the Pesochnoe 1 settlement, the studied samples of the background soils do not contain sand particles.

Elemental analysis of 349 samples of the Bronze Age cultural layer carried out by the XRF method showed the following contents of $\mathrm{Cu}, \mathrm{Zn}, \mathrm{P}$ and $\mathrm{Ca}$ in the samples: $\mathrm{Cu}$ from $0.007 \%$ to $0.015 \%, \mathrm{Zn}$ from $0.035 \%$ to $0.05 \%$, Ca from $8 \%$ to $12 \%$, P from $8 \%$ to $10 \%$. The comparative XRF elemental analysis of the one sample from pit No.1, showed the following contents of $\mathrm{Cu}, \mathrm{Zn}, \mathrm{P}$ and $\mathrm{Ca}: \mathrm{Cu}-0.0085 \%$, $\mathrm{Zn}-0.038 \%, \mathrm{Ca}-9 \%, \mathrm{P}-8 \%$. The contents of $\mathrm{Cu}, \mathrm{Zn}, \mathrm{P}$ and $\mathrm{Ca}$ in the one sample of the Bronze Age cultural layer from pit No.1 fit into the ranges of the presence of these chemical elements in the samples of the Bronze Age cultural layer from excavation No.3. This suggests that the content of $\mathrm{Cu}, \mathrm{Zn}, \mathrm{P}$ and $\mathrm{Ca}$ in the cultural layer of the Bronze Age of the entire settlement Pesochnoe 1 is within the range of values recorded in excavation No.3.

The XRF analysis of the soil sample from pit " $\mathrm{A}$ ", representing the background soils near the Pesochnoe 1 settlement, showed the following contents of $\mathrm{Cu}, \mathrm{Zn}, \mathrm{P}$ and $\mathrm{Ca}: \mathrm{Cu}-0.001 \%, \mathrm{Zn}-0.0035 \%$, $\mathrm{Ca}-1 \%, \mathrm{P}-0.3 \%$. The content of $\mathrm{Cu}, \mathrm{Zn}, \mathrm{P}$ and $\mathrm{Ca}$ recorded in the soil sample from pit " $\mathrm{B}$ ", determined by the XRF method and obtained from the sample of the background soil collection spot away from the Pesochnoe 1 settlement, was: $\mathrm{Cu}-0.002 \%, \mathrm{Zn}-0.004 \%, \mathrm{Ca}-1 \%, \mathrm{P}-0.15 \%$.

In the soil samples from pits " $\mathrm{A}$ " and " $\mathrm{B}$ ", the same $\mathrm{Ca}$ content and similar contents of $\mathrm{Cu}$ and $\mathrm{Zn}$ were recorded. The P content in the soil sample from the pit located near the Pesochnoe 1 settlement (Pit " $\mathrm{A}$ ") is two times higher than in the sample of buried soils from the pit located away 
from the settlement (Pit "B"). However, comparing the contents of $\mathrm{Cu}, \mathrm{Zn}, \mathrm{P}$, and $\mathrm{Ca}$ in the Bronze Age cultural layer of the Pesochnoe 1 settlement, recorded in samples of the Bronze Age cultural layer from excavation No.3 and pit No.1, the content of these elements in background soils is minimal. In comparison with the values from the background soils near the settlement Pesochnoe 1 (pit " $\mathrm{A}^{\prime \prime}$ ) the higher values were recorded for $\mathrm{Cu}$ content in the cultural layer 7-15 times, $\mathrm{Zn} \mathrm{10-14.28} \mathrm{times,}$ Ca 8-12 times, and P 26.66-33.33 times. In comparison with the values from the background soil

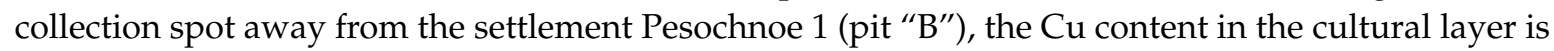
4-7.5 times higher, Zn 8.75-12.5 times, Ca 8-12 times, and P 53.33-66.66 times. This indicates that the content of $\mathrm{Cu}, \mathrm{Zn}, \mathrm{P}$ and $\mathrm{Ca}$ in the cultural layer of the Bronze Age of the settlement Pesochnoe 1 is a result of economic activity. The results of the XRF analysis of samples of the cultural layer of the Bronze Age of the Pesochnoe 1 settlement and samples of background soils in general are presented in Table 1. The distribution of the contents of $\mathrm{Cu}, \mathrm{Zn}, \mathrm{P}$ and $\mathrm{Ca}$ in excavation No.3 is shown in more detail in Figures 6-9.

XRF analysis revealed very high content of $\mathrm{Cu}, \mathrm{Zn}, \mathrm{Ca}$ and $\mathrm{P}$ in the cultural layer of the Pesochnoe 1 settlement, which had never been seen in prehistoric settlements in central Russia. In other studied prehistoric settlements of central Russia, the content of these elements in the cultural layer did not exceed their amount in the background soils. This is very unusual, but these results are only comparable to some singular indicators recorded in cultural strata of the Middle Ages and the new time of the city Rostov the Great (Figure 10) and other ancient towns in Russia [20]. It is a well-known fact that there was active artisanal and economic activity in all ancient cities. However in this case, the traces of economic activity in the settlement Pesochnoe 1, expressed in the content of $\mathrm{Cu}, \mathrm{Zn}, \mathrm{P}$ and $\mathrm{Ca}$ in the cultural layer of the Bronze Age, are comparable and even superior to similar traces to those of a city like Rostov the Great (founded in 862 AD), and they existed for more than a thousand years. This is an important historical association that allows us to understand the scale of economic activity that took place in this prehistoric settlement in the first half of the second millennium BC in central Russia.

Table 1. The Pesochnoe 1 settlement. The content of $\mathrm{Cu}, \mathrm{Zn}, \mathrm{Ca}$ and $\mathrm{P}$ in the cultural layer of the settlement and background soils beyond by XRF analysis.

\begin{tabular}{ccccc}
\hline $\begin{array}{c}\text { Chemical } \\
\text { Elements }\end{array}$ & $\begin{array}{c}\text { The Cultural Layer of the } \\
\text { Bronze Age. } \\
\text { Excavation No.3 } \\
\text { (349 Samples) }\end{array}$ & $\begin{array}{c}\text { The Cultural Layer of the } \\
\text { Bronze Age. } \\
\text { Pit No. 1 } \\
\text { (1 Sample) }\end{array}$ & $\begin{array}{c}\text { Background Soil Values } \\
\text { Near the Settlement. } \\
\text { Pit “A”. } \\
\text { (1 Sample) }\end{array}$ & $\begin{array}{c}\text { Background Soil Values } \\
\text { Away from the Settlement. } \\
\text { Pit “B”. } \\
\text { (1 Sample) }\end{array}$ \\
\hline $\mathrm{Cu}(\%)$ & $0.007-0.015$ & 0.0085 & 0.001 & 0.002 \\
\hline $\mathrm{Zn}(\%)$ & $0.035-0.05$ & 0.038 & 0.0035 & 0.004 \\
\hline $\mathrm{Ca}(\%)$ & $8-12$ & 9 & 1 & 1 \\
\hline $\mathrm{P}(\%)$ & $8-10$ & 8 & 0.3 & 0.15 \\
\hline
\end{tabular}




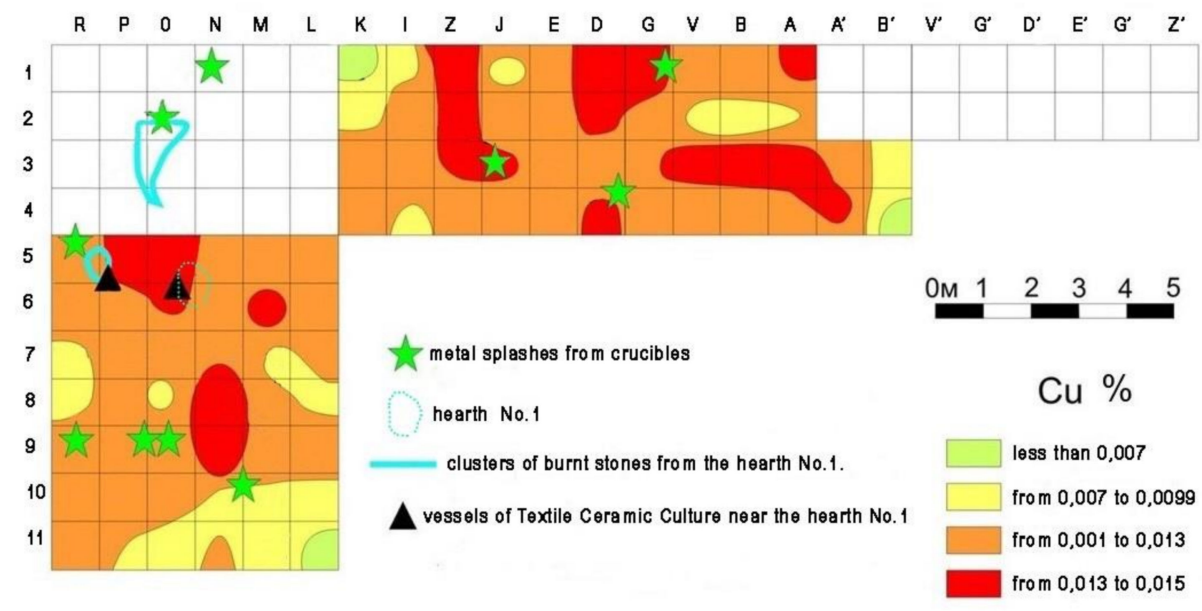

(a)

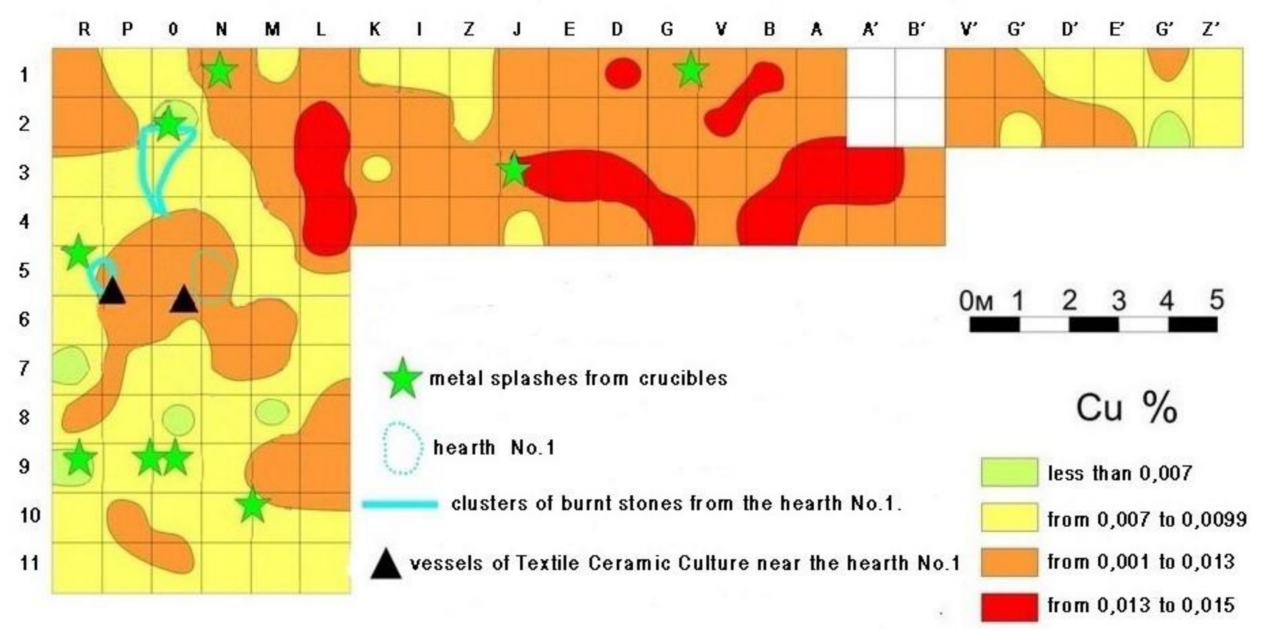

(b)

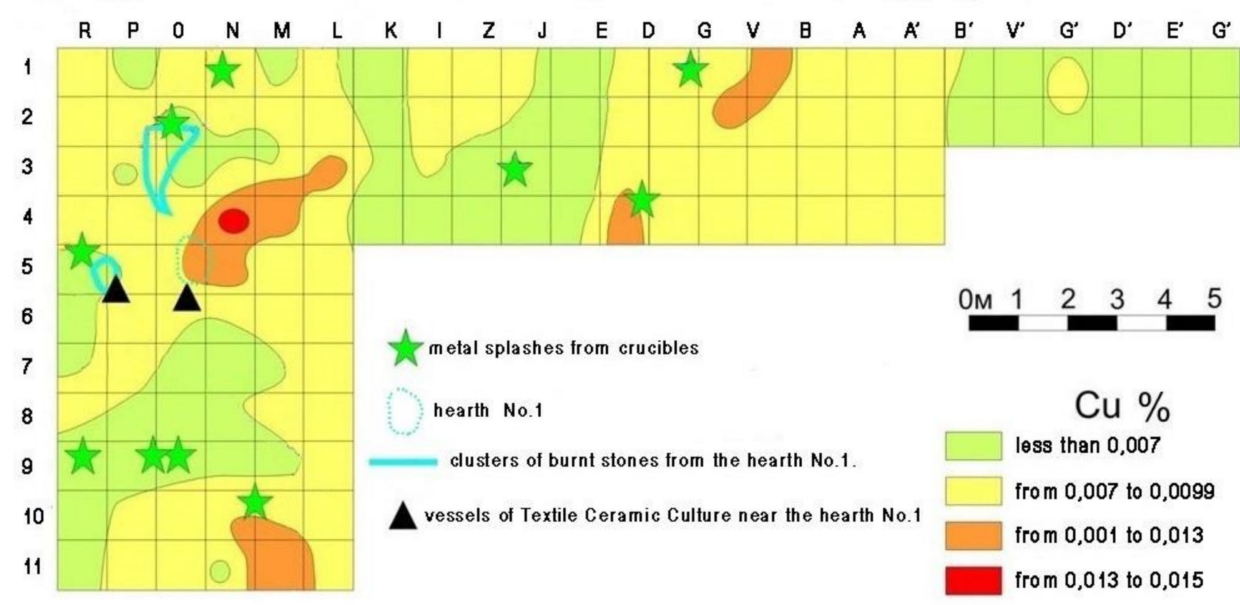

(c)

Figure 6. Distribution of $\mathrm{Cu}$ content in the cultural layer; (a) 1 "top"; (b) 1 "bottom"; (c) 2 "bottom". 


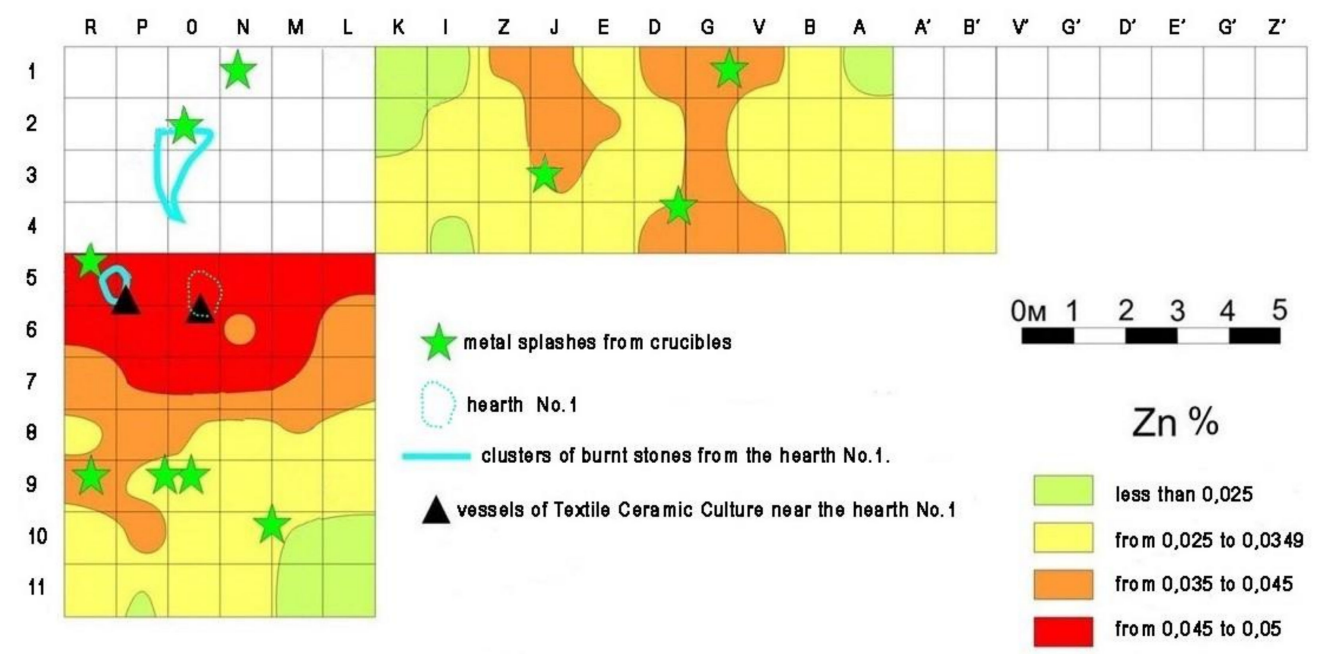

(a)

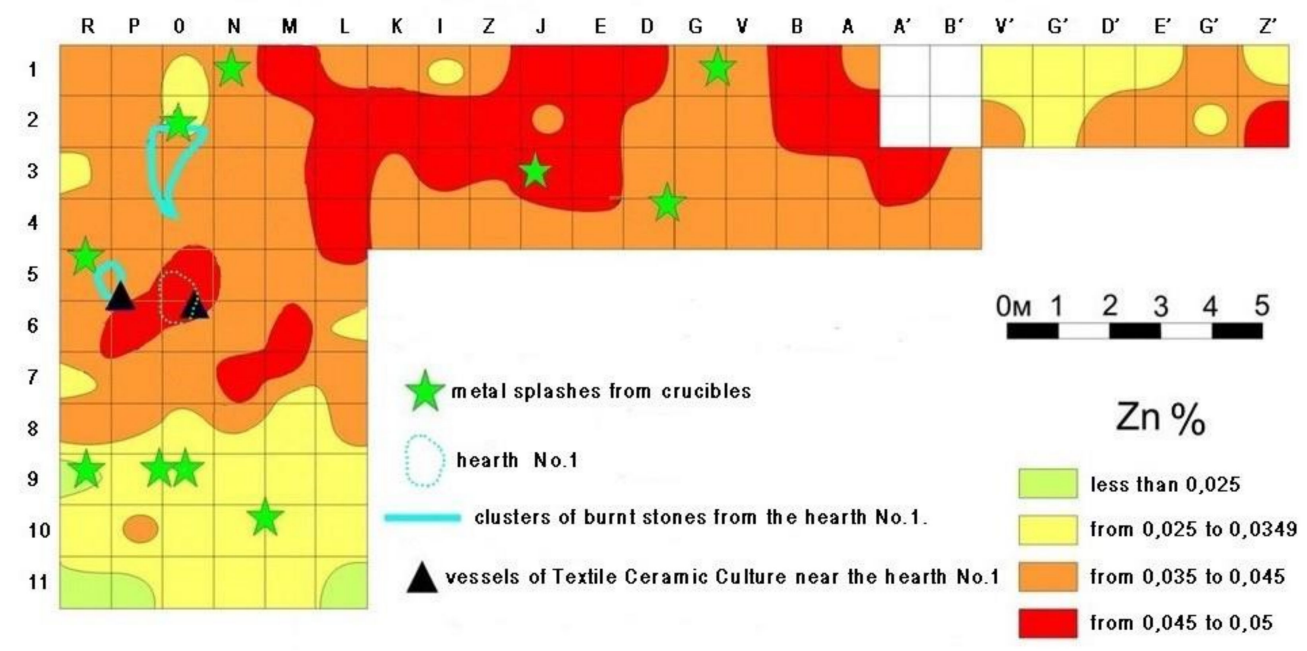

(b)

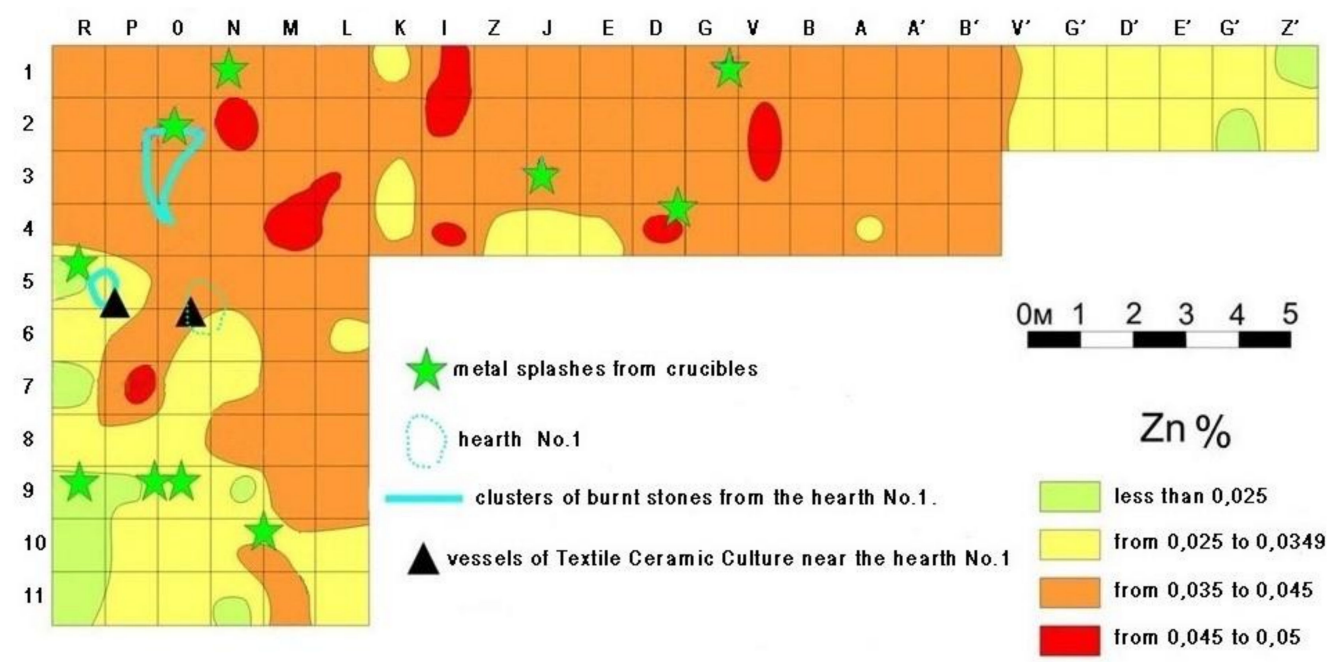

(c)

Figure 7. Distribution of Zn content in the cultural layer; (a) 1 "top"; (b) 1 "bottom"; (c) 2 "bottom". 


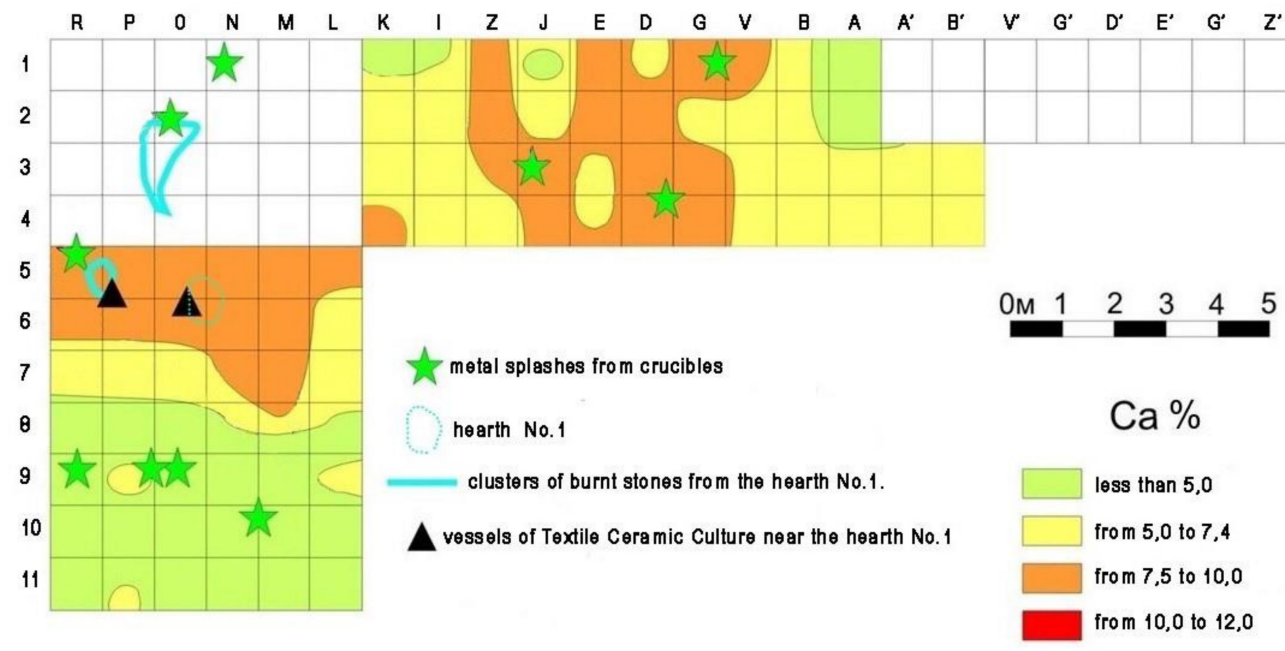

(a)

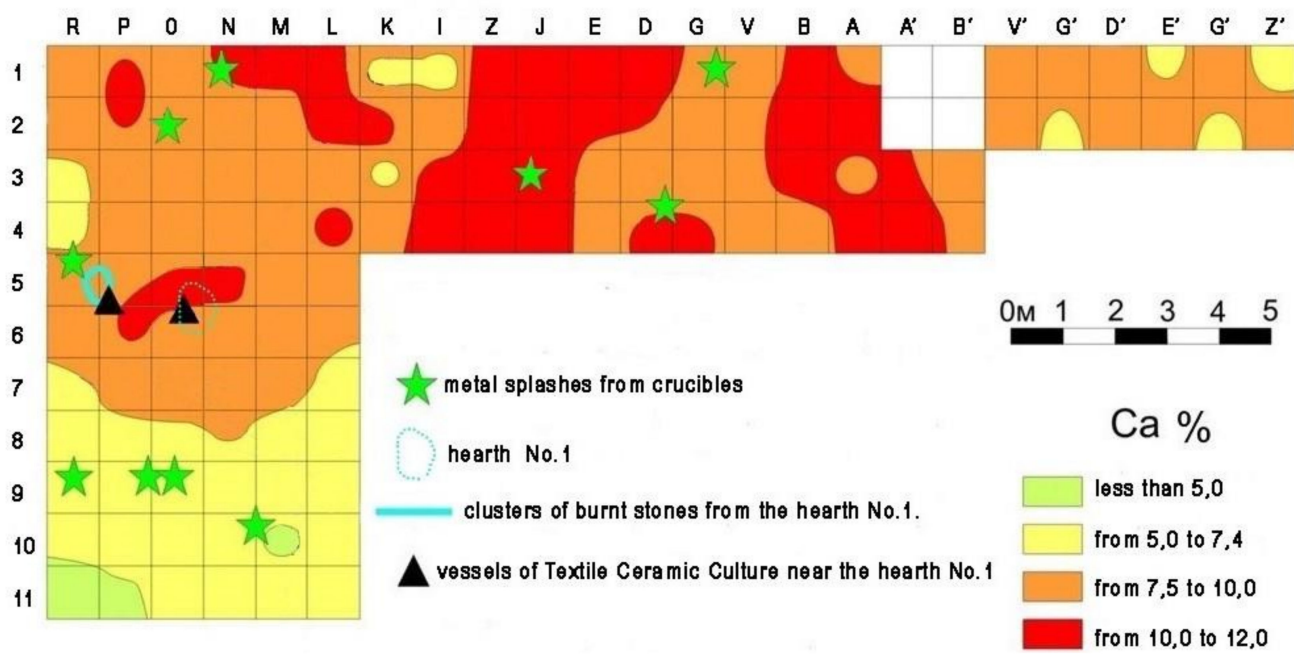

(b)

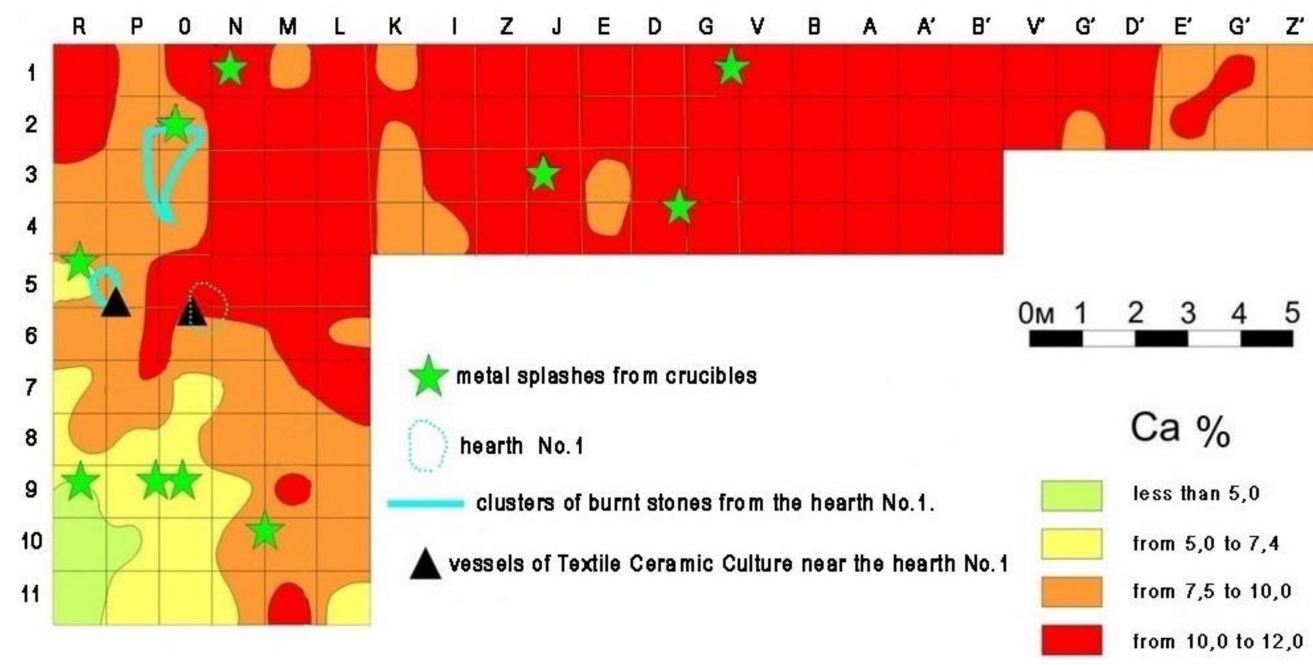

(c)

Figure 8. Distribution of Ca content in the cultural layer; (a) 1 "top"; (b) 1 "bottom"; (c) 2 "bottom". 


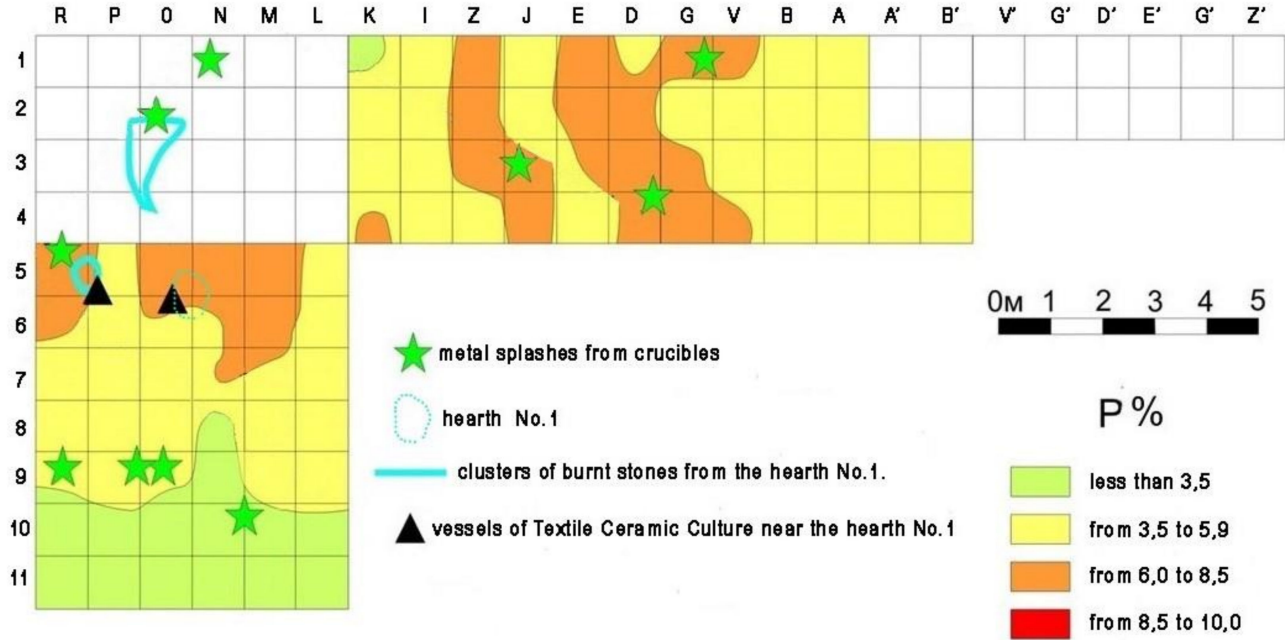

(a)

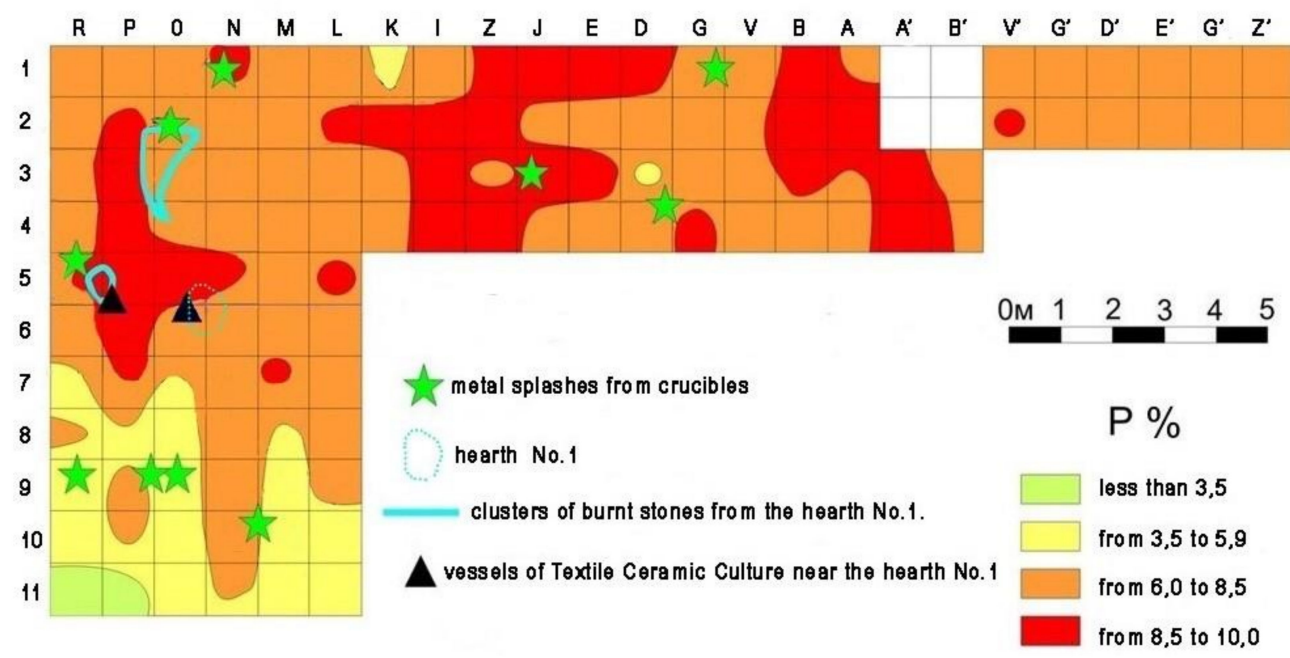

(b)

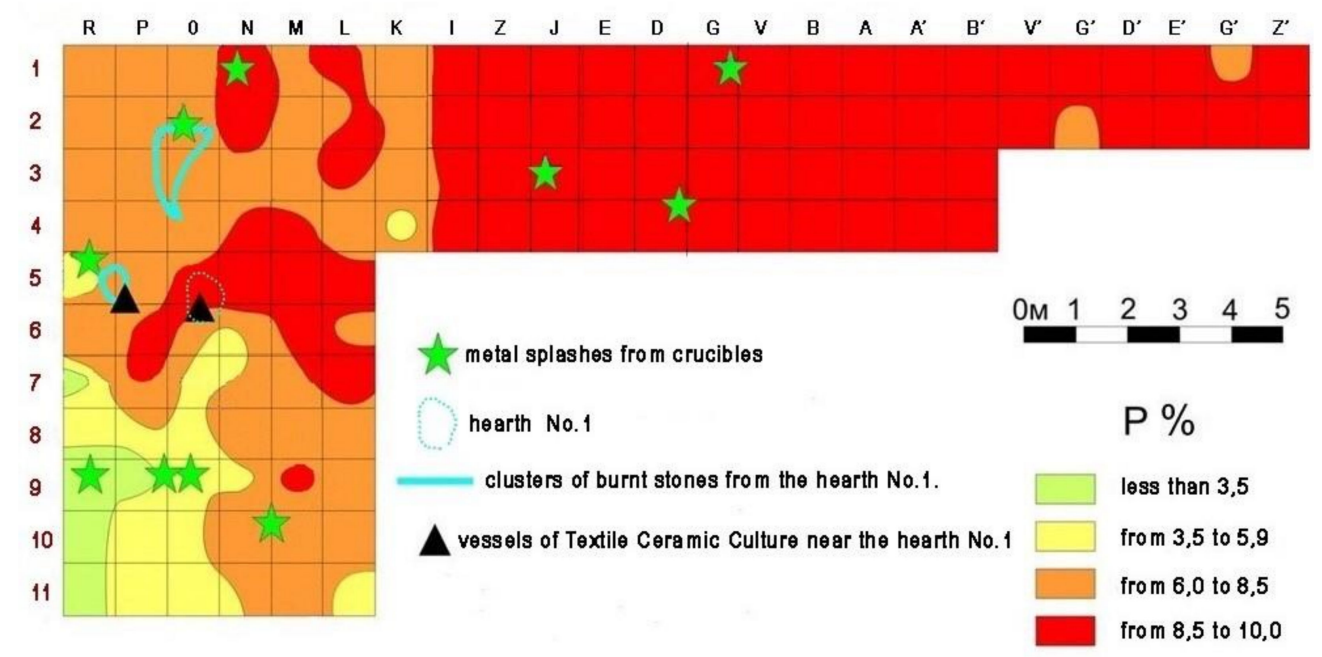

(c)

Figure 9. Distribution of P content in the cultural layer; (a) 1 "top"; (b) 1 "bottom"; (c) 2 "bottom". 


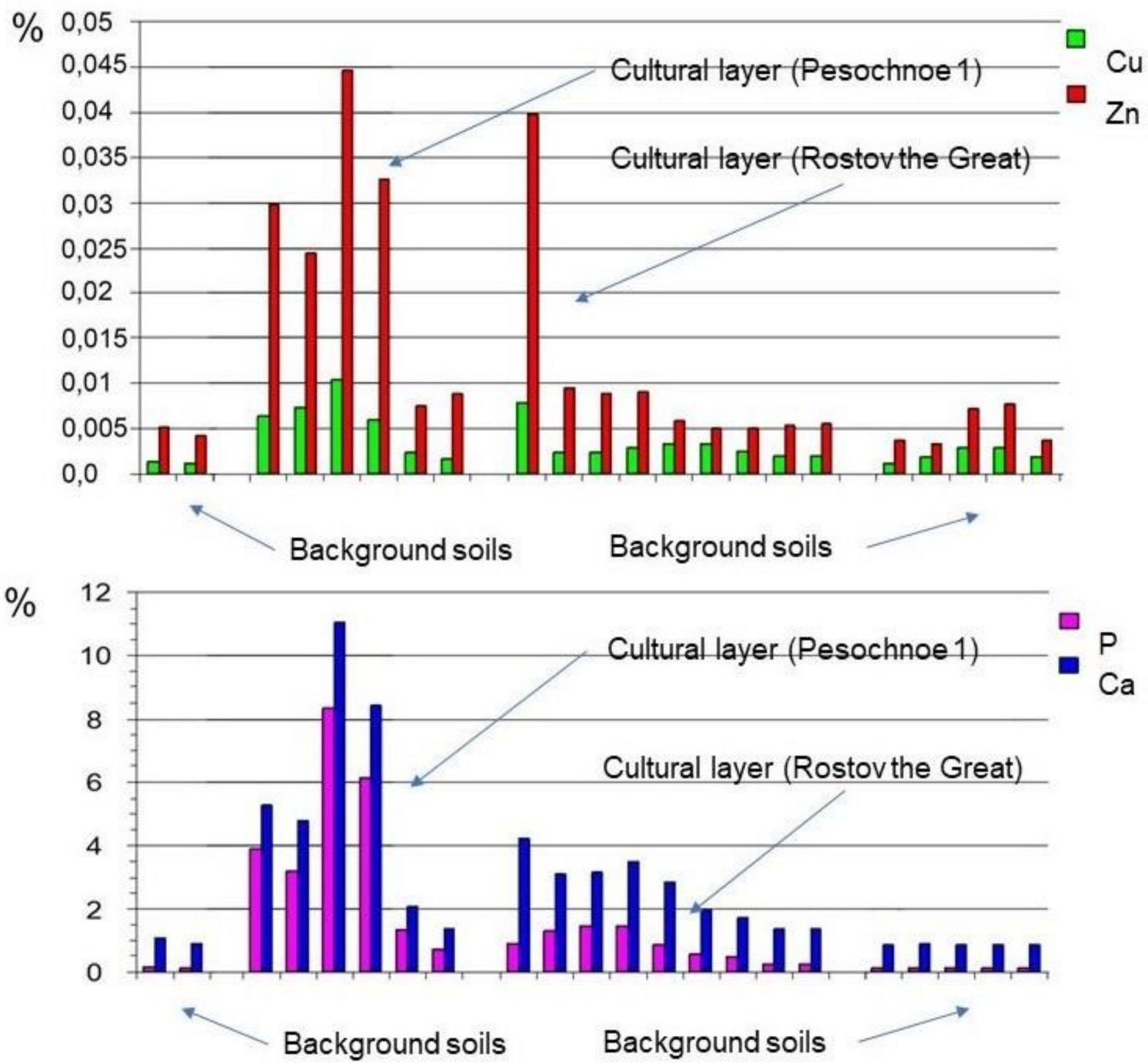

Figure 10. The content of $\mathrm{Cu}, \mathrm{Zn}, \mathrm{P}, \mathrm{Ca}$ in the background soils, the cultural layer of the Bronze Age settlement Pesochnoe 1 and the cultural layer of the medieval city of Rostov the Great.

4.2. Spatial Distribution of the Indicators of Content of $\mathrm{Cu}, \mathrm{Zn}, \mathrm{Ca}$ and $\mathrm{P}$ in the Cultural Layer in the Studied Part of the Pesochnoe 1 Settlement

Analysis of the spatial distribution of $\mathrm{Cu}, \mathrm{Zn}, \mathrm{P}$ and $\mathrm{Ca}$ in the cultural layer of the Bronze Age in excavation No.3, determined by the method of XRF analysis, showed that their maxima coincide with the places of the highest concentration of fragments of ceramics with textile decor (Figure 11), The presence of these weakened the influence of natural factors in the cultural layer, such as its washing out with groundwater and interference of insects and underground animals. These fragments of textile ceramics belong to the same archaeological complex. Due to the large number of pieces, the distribution of fragments of textile ceramics in Excavation No.3 is shown on two separate plans (Figure 11a-Excavation No.3, stratum 1; Figure 11b-Excavation No.3, stratum 2).

The distribution of $\mathrm{Cu}$ at the levels of 1 "top" and 1 "bottom" (Figure 6a,b) correlated with the distribution of textile ceramics areas in the most detail. This probably led to smaller diffusion of chemical elements from the soil at the places of accumulation of ceramic fragments and led to higher values of the contents of $\mathrm{Cu}$ (Figure 6), Zn (Figure 7), Ca (Figure 8) and P (Figure 9) in squares with a large number of ceramic fragments. 


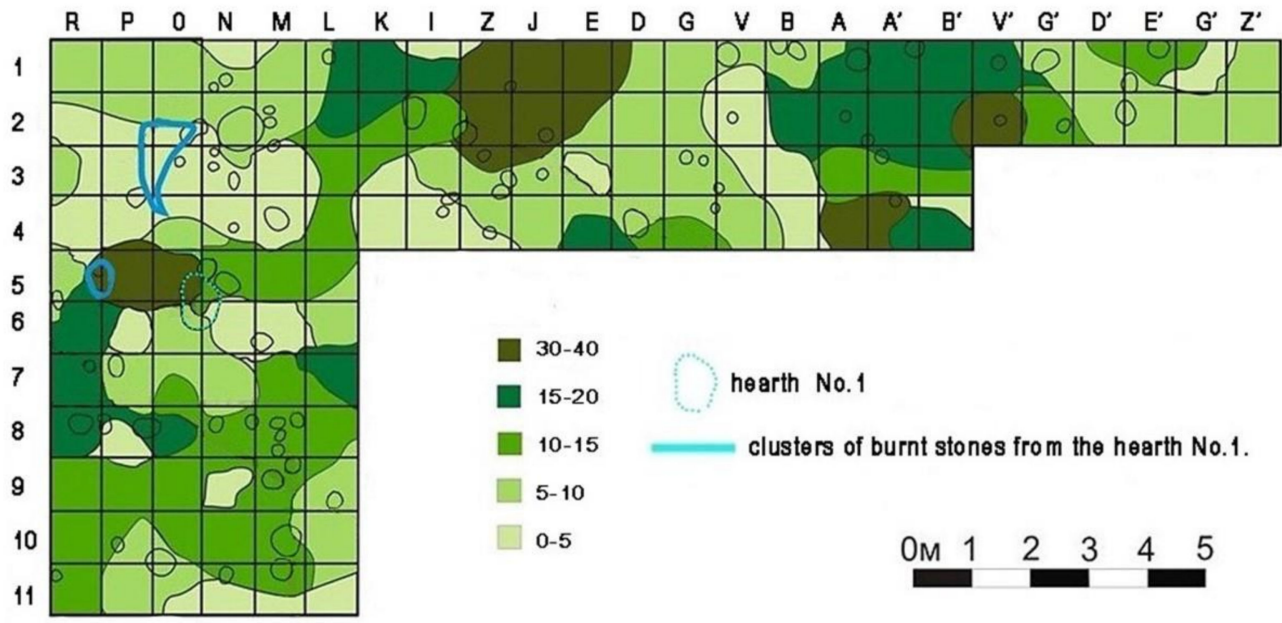

number of fragments of ceramics with textile decoration per $1 \mathrm{~m}^{2}$

(a)

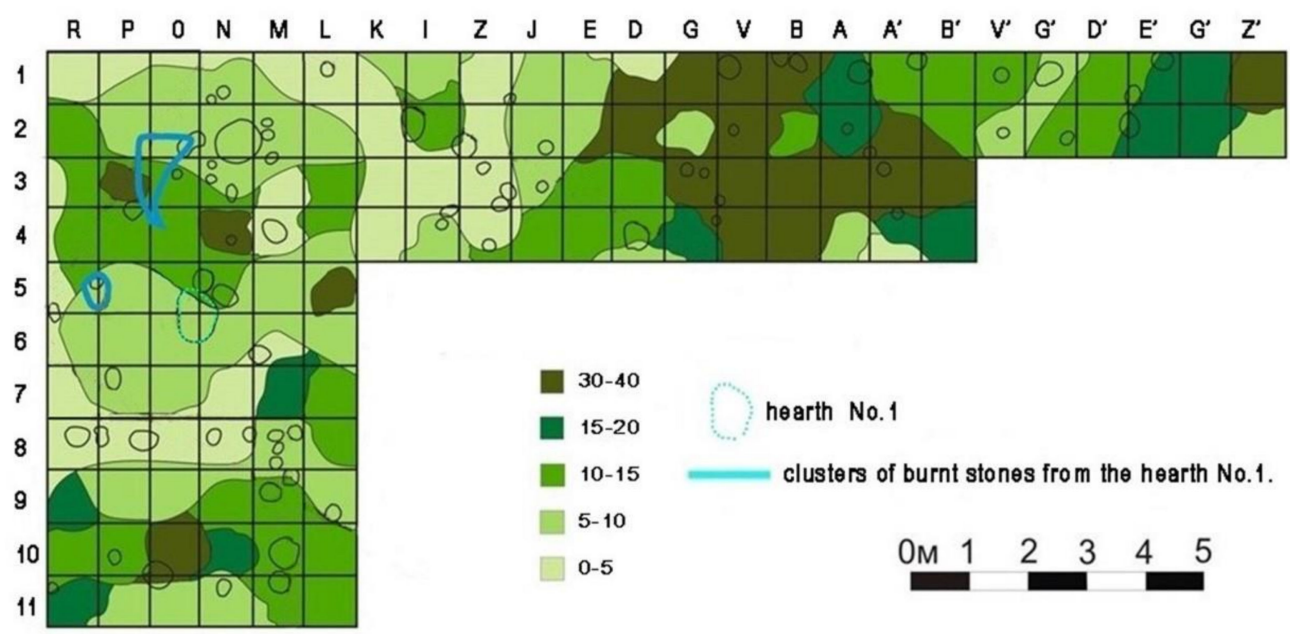

number of fragments of ceramics with textile decoration per $1 \mathrm{~m}^{2}$

(b)

Figure 11. Statistical distribution of fragments of ceramics with textile decor in the excavation No.3;

(a) layer 1; (b) layer 2.

Spatial distribution of the indicators of the content of $\mathrm{Cu}, \mathrm{Zn}, \mathrm{Ca}$ and $\mathrm{P}$ in the cultural layer was analyzed in relation to the location of archaeological objects and pieces found in them or nearby. It was assumed that this would make it possible to identify functional areas in the studied part of the settlement or to obtain data to determine the shape, size and boundaries of ground structures. The remains of non-deepened structures of the Bronze Age were marked in the excavation by segments of postholes chains, located inside or outside the perimeters of spaces with clusters of calcined stones, a calcined hearth spot, utility pits, vessels of the textile ceramic culture, traces of metalwork, stone and clay products (Figures $2-4,11$ and 12 ).

One particular group of objects forming a single archaeological complex stands out, distinguished by the planographic positioning of the objects and the logic of the functional interconnectedness of the artifacts. The center of this complex was hearth No.1, from which there remained a long stretched to the north spot of calcined soil measuring $1.2 \mathrm{~m} \times 0.75 \mathrm{~m}$ (Figures 2 and 3), located in squares "N-5, N-6"-"O-5, O-6". In the space adjacent to it, 1.3-1.8 m west in the squares "P-5", "R-5" and $0.9-2.5 \mathrm{~m}$ west-northwest in the squares "O-2, O-3, O-4"-“P-2, P-3, P-4" there were two clusters of calcined stones. Near hearth No.1, $1.2 \mathrm{~m}$ to the west-south-west, in squares "P-5, P-6", and $0.7 \mathrm{~m}$ to 
the south in squares "N-6, O-6", there were two hollow round-bottom vessels with a textile ornament (Figure 3), the presence of which testified to the fact that this archaeological complex belonged to the textile ceramic culture (Figure 2, 30 in Figure 4).

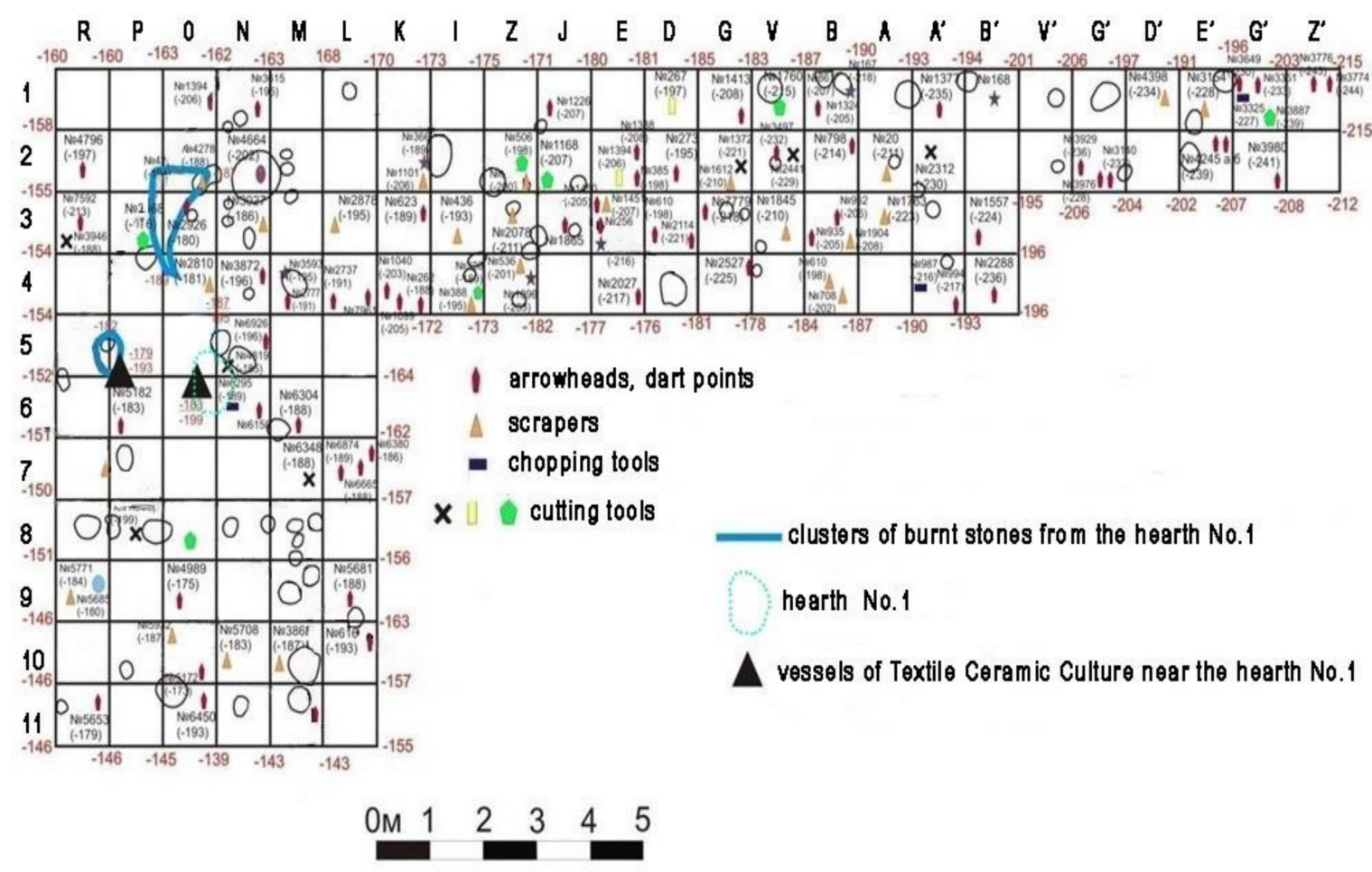

Figure 12. Location of stone tools in the excavation-arrowheads, dart points, scrapers, chopping tools, cutting tools.

Around hearth No.1, at a distance of 2-10.5 m, 11 metal drops were found, which proved to be splashes from crucibles (Figure 2, 20,21 in Figure 4). Additionally, in hearth No.1 and in the surrounding space on an area of about $41 \mathrm{~m}^{2}$, very high concentrations of $\mathrm{Cu}$ (Figure 6), Zn (Figure 7a,b), Ca (Figure 8) and $P$ (Figure 9) were observed to manifested themselves particularly clearly at the sample collection levels 1 "top" and 1 "bottom". The boundaries of these chemical elements' positions differed in detail: they were superimposed on each other with a slight displacement, but their spatial distribution still coincided with the location of hearth No.1. For example, the area of concentration of $\mathrm{Cu}(0.013-0.015 \%)$ with the maximum surface at level 1 "top" of about $2.5 \mathrm{~m}^{2}$ was the most compact (Figure 6a). The $\mathrm{P}$ territory (6-8.5\%) turned out to be slightly larger-its tracked maximum area at level 1 "top" was about $7 \mathrm{~m}^{2}$ (Figure 9a). The $\mathrm{Zn}(0.045-0.05 \%)$ and $\mathrm{Ca}(7.5-10 \%)$ disposition areas were more extensive (recorded areas at the level 1 "top" of 13-14 $\mathrm{m}^{2}$ ) and comparable in shape (Figures 7a and 8a).

In the immediate vicinity of the complex of hearth No.1 with textile ceramics, a significant number of stone objects was located, most of which lay east of the first hearth forming a vast cluster of objects scattered over $57 \mathrm{~m}^{2}$ area, starting from the line of squares "N-1"-“N-7" (Figure 12). Among flint objects, two series of instruments were most numerous: 92 scrapers $(8,9,11$ in Figure 4$)$ and 75 items of projectile weaponry (1-5 in Figure 4). The stone tools of the Bronze Age found in the excavation are associated with one archaeological complex, and their location in excavation No.3 is shown on the same plan (Figure 12) indicating the depth of their occurrence in the cultural layer, determined from the geodetic reference point. According to the elemental composition of the cultural layer, the second zone was characterized by a more uniform spatial distribution of high Zn values (0.035-0.0465\%), and especially high values of $\mathrm{Ca}(10-12 \%)$ and $\mathrm{P}(8.5-10 \%)$ - the main spatial distribution of which coincided with the zone of distribution of stone tools (Figure $7 b, c$, Figure $8 b, c$, Figure $9 b, c$ and Figure 12). A tendency 
toward an increase in the content of Ca (Figure 8) and P (Figure 9) in the cultural layer with an increase in the depth of sampling was observed.

The adjoining territories of artifact complex of hearth No.1 and the accumulation of stone tools present great interest. This indicates the interconnection of these micro-territories and, probably, the similar ages of the artifacts in them. Furthermore, these two micro-territories can be categorized together by spatial distribution of clusters with high concentrations of $\mathrm{Cu}, \mathrm{Zn}, \mathrm{Ca}$ and $\mathrm{P}$ around the excavation area. The individual boundaries of every element may have varied, but as a whole, they demonstrate a similar arrangement and correlate with each other spatially. Together with the boundaries of the $\mathrm{Cu}, \mathrm{Zn}, \mathrm{Ca}$, and $\mathrm{P}$ locations, which could be laid one upon the other, within the excavation area, a site of about $100 \mathrm{~m}^{2}$ was localized (Figures 6-9 and 12). It is oriented to cardinal points with slight deviations and includes the complex of hearth No. 1 with ceramics of textile ceramic culture and the accumulation of stone weaponry. Reliably traceable the southern border (by which the site was possible to determine) fluctuates between squares "R-7"-“L-11".

In the southern boundaries of the $\mathrm{Cu}$ zones, $\mathrm{Zn}, \mathrm{Ca}$ and $\mathrm{P}$ are marked: for $\mathrm{Zn}$ in the "L-R 8" square strip (Figure 7a,b), for Ca along the strip of squares "L-R 8" (Figure 8b,c), for $P$ along the strip of squares "L-R 8-9" (Figure 9b,c). Zn, Ca, P zones adjoined two lines of postholes located along the stripes of squares "M-P 8"; "M 8-11", and the conjugation of which formed a straight angle of a building. The virtual outer borders of which, however, did not intersect with $\mathrm{Zn}, \mathrm{Ca}$, P. For the $\mathrm{Cu}$ zones, the southern border was blurred, representing an uneven line between the "K-10" and "R-11" squares (Figure 6a).

The $\mathrm{Cu}$ zone was the most heterogeneous in structure. It mainly consisted of interspersed sections with uneven borders with $\mathrm{Cu}$ concentrations of $0.007-0.0099 \%$ and $0.01-0.013 \%$, between which there were small separated areas ranging from $0.7 \mathrm{~m}^{2}$ to $4 \mathrm{~m}^{2}$ with very high content of $\mathrm{Cu}$ of more than $0.013 \%$. The findings of metal droplets, which turned out to be splashes from crucibles, were located only in the left half of the excavation, where hearth No. 1 was situated, but their distribution was not always correlated with certain concentrations of $\mathrm{Cu}$ (Figure 6). The structure of the $\mathrm{Zn}$ zone was more uniform. In most of its space, $\mathrm{Zn}$ content was $0.035-0.045 \%$. Within the $\mathrm{Zn}$ zone, its content in hearth No.1 in some areas was more than $0.045 \%$ (Figure 7). The Ca and P zones had an even more uniform spatial structure (Figures 8 and 9). At level 1 of the excavation, the content of Ca was mainly 7.5-10\%, at the level of layer 2, the content of Ca was $10 \%$ higher than in most of the excavation. The content of $\mathrm{P}$ at level 1 of the excavation was mainly $6-8.5 \%$, while at the level of layer 2 of the excavation, the main content of $\mathrm{P}$ was more than $8.5 \%$. The distribution of the maximum contents of $\mathrm{Ca}$ and $\mathrm{P}$, which are products of organic decay, coincided (Figure 8b,c, Figure 9b,c and Figure 12) with the spatial arrangement of most stone tools, among which flint scrapers and flint arrowheads dominate.

\section{Discussion}

The high content of $\mathrm{Cu}, \mathrm{Zn}, \mathrm{Ca}$, and $\mathrm{P}$ in the cultural layer, which has most certainly stayed intact since the Bronze Age, is undoubtedly due to the geochemical conditions formed in the cultural layer and the properties of the chemical compounds formed in it with the help of $\mathrm{Cu}, \mathrm{Zn}, \mathrm{Ca}$, and $\mathrm{P}$. The absorbing properties of humic substances present in the cultural layer and the poor solubility of humic acids contributed to the accumulation of certain trace elements in humus. Humic acids are mainly accumulated in the place of their formation, thus forming derivatives of organic-mineral compounds with amphoteric metals [21-23], and thus affecting the characteristics of elemental soil composition within certain territories.

This explains why $\mathrm{Cu}$ and $\mathrm{Zn}$ accumulated in the cultural layer of the Pesochnoe 1 settlement after interaction with the humic acids were detected in the humus of the cultural layer. Determination of the elemental composition of metal in metal outbursts from crucibles found in the cultural layer of the Bronze Age in excavation No.3 of Pesochnoe 1, detected tin (Sn) in the composition of alloys [24], which is also an amphoteric metal like $\mathrm{Cu}$ and $\mathrm{Zn}$. However, the recorded quantities of $\mathrm{Sn}$ in the cultural layer of the Bronze Age were less than $5 \mathrm{ppm}$ and, therefore, this metal cannot be considered as 
a geochemical indicator of economic activity in the Pesochnoe 1. The fact that Sn was not accumulated in the cultural layer of the Bronze Age of the settlement Pesochnoe 1 is probably due to the fact that its quantity in alloys used in central Russia in the Bronze Age period was about 10\%, therefore, in the Pesochnoe 1 settlement, the potential amount of Sn was approximately nine times less than $\mathrm{Cu}$. Furthermore, $\mathrm{Sn}$ was much less commonly used in alloys in comparison with $\mathrm{Cu}$ in central Russia in the second millennium BC. Copper tools were used in large quantities in the Bronze Age, and this appears to also be true for the Pesochnoe 1 settlement since the fragment of copper tool was found on it in the cultural layer of the Bronze Age (19 in Figure 4).

In turn, according to the results of XRD analysis, five samples of the cultural layer from hearth No.1, examined using the same methodology [25], demonstrate that Ca and P are present in the cultural layer mainly as hydroxylapatite $\mathrm{Ca}_{5}\left(\mathrm{PO}_{4}\right)_{3} \mathrm{OH}$. This fact undoubtedly contributes to their high stability in soil.

$\mathrm{Cu}, \mathrm{Zn}, \mathrm{Ca}$ and $\mathrm{P}$ entered the cultural layer from various sources. Along with $\mathrm{Ca}$ and $\mathrm{P}, \mathrm{Zn}$ and $\mathrm{Cu}$ are chemical elements necessary for the life cycle of living organisms. Their entry into the cultural layer as products of life activity could only have occurred in small quantities. Their high concentration in the cultural layer is undoubtedly a consequence of human activity $[6,26]$. In this case, the spatial distribution of peaks of high $\mathrm{Cu}$ content coinciding with the location of hearth No.1 and corresponding metalworking artefacts is undoubtedly related to the metalworking process that took place in the Bronze Age. The marked dispersed and inhomogeneous structure of $\mathrm{Cu}$ zones may be related to the fact that $\mathrm{Cu}$ got into the cultural layer from vapors formed during melting and working of metal. Areas of contamination of the metal working site proved the existence of experimental metal melting with the Bronze Age technology. This was shown by the presence of metal traces vaporized from alloys adsorbed in the soil and containing high concentrations of $\mathrm{Cu}$ [27], similar in location to the high $\mathrm{Cu}$ contents recorded in the complex of the hearth No.1.

$\mathrm{Zn}$, on the contrary, is not related to metal processing. As a component of alloys, it was not known in the Bronze Age. It would be hypothetically possible to assume the presence of this metal as a natural impurity in the metals melted in the settlement (copper, tin or bronze), but $\mathrm{Zn}$ is absent in the elemental composition of the metal artifacts found in the Pesochnoe 1 settlement [24]. It has been repeatedly noted that elevated levels of $\mathrm{Zn}$, along with $\mathrm{P}$, imply organic deposits and may also indicate traces of ash, such as burnt turf or manure, which may have been used as fuel [3,6]. In this regard, when assessing the presence of $\mathrm{Zn}$ in the cultural layer of the Bronze Age settlement Pesochnoe 1, it is necessary to take into account the fact of its location on the lake shore. Zn is very important for the life of aquatic organisms and plants. For example, fish accumulate it very active [28-30]. This gives a reason to evaluate its presence also in a way as traces of biomass from the aquatic environment, extracted by the inhabitants of the Bronze Age settlement from the nearby Lake Nero.

The existing high concentrations of $\mathrm{P}$ in the cultural layer can be considered partially as a result of the decomposition of organic residues [3]. However, the main source of Ca and P is undoubtedly the bone remnants contained in the cultural layer. According to the XRD analysis, Ca and P are present in the cultural layer of the Pesochnoe 1 settlement mainly in the form of hydroxylapatite $\mathrm{Ca}_{5}\left(\mathrm{PO}_{4}\right)_{3} \mathrm{OH}$, which serves as mineral basis of bone tissue and teeth [31]. A comparison of the results of the XRD of five samples of the cultural layer taken from and around hearth No.1 with the test result of the XRD analysis of the sample of the burned cow bone shows that these samples contain precisely hydroxylapatite $\mathrm{Ca}_{5}\left(\mathrm{PO}_{4}\right)_{3} \mathrm{OH}$. This suggests that the hydroxylapatite from the studied samples of the cultural layer is actually the product of bone burning, which, in this case, is present in large quantities in the deposits of the Pesochnoe 1 settlement in a finely dispersed form (Figure $5 b$ ).

\section{Conclusions}

The spatial distribution of the zones of $\mathrm{Cu}, \mathrm{Zn}, \mathrm{Ca}$ and $\mathrm{P}$ in the cultural layer of the Bronze Age of the settlement Pesochnoe 1, dated to the first half of the second millennium BC, in correlation with the location of objects and artifacts in the excavation, determines the existence of two conjugate functional 
zones of the settlement. The first one with an area of $41 \mathrm{~m}^{2}$ is formed by a complex of hearth No.1 with two vessels of the textile ceramic culture and two clusters of fired stones. Very high concentrations of $\mathrm{Cu}, \mathrm{Zn}, \mathrm{Ca}, \mathrm{P}$ have been detected. They demonstrate the traces of various activities held in this territory, including the use of organic materials $(\mathrm{Zn})$, possibly related to the aquatic environment, as fuel, the use of bone as fuel $(\mathrm{Ca}, \mathrm{P})$ and the melting and working of metal $(\mathrm{Cu})$, which led to the abundant deposition of copper at the metal processing site. The second area of $57 \mathrm{~m}^{2}$ was represented by an abundant number of stone tools, among which various scrapers and projectile weaponry dominated. The largest part of the second functional zone was located to the east of hearth No.1. The maximum peaks in the content of $\mathrm{Zn}$ and, especially of $\mathrm{Ca}$ and $\mathrm{P}$, coincided with the location of this zone, which indicates the former presence of a large amount of organic matter at this place. According to the spatial correlation of the large amounts of flint tools located in one place with very high spatial contents of $\mathrm{Zn}$ in the cultural layer, which perhaps was a trace of the biomass of the aquatic environment, as well as $\mathrm{Ca}$ and $\mathrm{P}$, which are part of the chemical compounds formed during the decay of bones and other organic materials, this functional zone can be generally interpreted as a place for processing biomaterials of animal origin (possibly hunting trophies, etc.). The spatial unity of these functional zones and the existence of common patterns for them in the distribution of the concentrations of $\mathrm{Cu}$, $\mathrm{Zn}, \mathrm{Ca}$ and $\mathrm{P}$ testify to the similar time of their existence and belonging to the textile ceramic culture. The positioning of the sites of maximum concentration of $\mathrm{Cu}, \mathrm{Zn}, \mathrm{Ca}$, and $\mathrm{P}$ outside the perimeters of postholes, which outlined the location of ancient structures, indicates that this space may have been located in an open area of the settlement, outside of any construction. The high content of $\mathrm{Cu}, \mathrm{Ca}, \mathrm{P}$, $\mathrm{Zn}$ in the cultural layer of the Bronze Age of the settlement of Pesochnoe 1, recorded by XRF analysis, reveals traces of metalworking and the active use of biological resources of water and surrounding territories by the inhabitants of the Pesochnoe 1 settlement. High concentrations of $\mathrm{Cu}$ in the cultural layer mark the Bronze Age metal processing in the settlement of Pesochnoe 1 to the first half of the second millennium BC, recording at the same time local pollution of the territory of this settlement with industrial metal processing wastes, typical for places of metal production in the prehistoric period $[2,8]$.

Funding: This research received no external funding.

Conflicts of Interest: The author declares no conflict of interest.

\section{References}

1. Homsher, R.S.; Tepper, Y.; Drake, B.L.; Adams, M.J.; David, J. From the Bronze Age to "Lead Age": Observations on sediment analyses at two archaeological sites in the Jezreel valley, Israel. Mediterr. Archaeol. Archaeom. 2016, 16, 203-220. [CrossRef]

2. Zhang, S.; Yang, Y.; Storozum, M.J.; Li, H.; Cui, Y.; Dong, G. Copper smelting and sediment pollution in Bronze Age China: A case study in the Hexi corridor, Northwest China. Catena 2017, 156, 92-101. [CrossRef]

3. Simniškytè-Strimaitienèa, A.; Selskienèb, A.; Vaičiūnienèb, J.; Pakštasb, V.; Ramūnas Šmigelskasa, R. Tracing Archaeology through Geochemistry: An Example of a Disturbed Prehistoric Hilltop Settlement Site in South-Eastern Lithuania. Interdiscip. Archaeol. 2017, 8, 17-33. [CrossRef]

4. Ouahabi, M.E.; Hubert-Ferrari, A.; Lebeau, H.; Karabacak, V.; Auwera, J.V.; Lepoint, G.; Dewitte, O.; Schmidt, S. Soil erosion in relation to land-use changes in the sediments of Amik Lake near Antioch antique city during the last 4 kyr. Holocene 2018, 28, 104-118. [CrossRef]

5. Smejda, L.; Hejcman, M.; Horak, J.; Shai, I. Multi-element mapping of anthropogenically modified soils and sediments at the Bronze to Iron Ages site of Tel Burna in the southern Levant. Quatern. Int. 2018, 483, 111-123. [CrossRef]

6. Smejda, L.; Hejcman, M.; Horak, J.; Shai, I. Ancient settlement activities as important sources of nutrients (P, K, S, Zn and Cu) in Eastern Mediterranean ecosystems-The case of biblical Tel Burna, Israel. Catena 2017, 156, 62-73. [CrossRef]

7. Cortizas, A.M.; López-Merino, L.; Bindler, R.; Mighall, T.; Kylander, M.E. Early atmospheric metal pollution provides evidence for Chalcolithic/Bronze Age mining and metallurgy in Southwestern Europe. Sci. Total Environ. 2016, 545-546, 398-406. [CrossRef] 
8. Mighall, T.M.; Timberlake, S.; Clark, S.H.E.; Caseldine, A.E. A Palaeoenvironmental Investigation of Sediments from the Prehistoric Mine of Copa Hill, Cwmystwyth, Mid-Wales. J. Archaeol. Sci. 2002, 29, 1161-1188. [CrossRef]

9. Hillman, A.L.; Abbott, M.B.; Yu, J.; Bain, D.J.; Chiou-Peng, T. Environmental Legacy of Copper Metallurgy and Mongol Silver Smelting Recorded in Yunnan Lake Sediments. Environ. Sci. Technol. 2015, 49, 3349-3357. [CrossRef]

10. Voronin, K.V. To the question of the origin and development of the Textile Ceramic Culture of the Bronze Age. Tverskoj Archeologichesky Sbornik 1998, 3, 309-323. (In Russian)

11. Lavento, M. Textile Ceramics in Finland and on the Karelian Isthmus: Nine Variations and Fugue on a Theme of C. F. Meinander, 1st ed.; Finnish Antiquarian Society: Helsinki, Finland, 2001; pp. 37-38.

12. Voronin, K.V. Results of the geoarchaeological study of the Bronze Age layer at the settlement Pesochnoe 1. KSIA 2018, 252, 87-103. (In Russian) [CrossRef]

13. Alexandrovsky, A.L.; Voronin, K.V.; Alexandrovskaya, E.I.; Dergacheva, M.I.; Mamontova, D.A.; Dolgikh, A.V. Natural science methods for studying multilayered prehistoric monuments with a homogeneous cultural layer (for example of the settlement Pesochnoe-1 on Lake Nero). Archeologiya Podmoskov'ya 2011, 7, 11-25. (In Russian)

14. Alexandrovsky, A.L.; Voronin, K.V.; Alexandrovskaya, E.I.; Mamontova, D.A.; Dolgikh, A.V. Soil-geochemical methods for studying stratigraphy of multilayer prehistoric settlements. Tverskoj Archeologichesky Sbornik 2013, 9, 79-91. (In Russian)

15. Alexandrovsky, A.L.; Voronin, K.V.; Dolgikh, A.V.; Kovalyukh, N.N.; Skripkin, V.V.; Glavatskaya, E.V. Radiocarbon studies of the cultural layer of the bronze-Neolithic settlement Pesochnoe 1 on Lake Nero. Archeologiya Podmoskov'ya 2012, 8, 35-44. (In Russian)

16. Alexandrovsky, A.L.; Voronin, K.V.; Dolgikh, A.V. Paleocene environment and stages of soil formation and cultural layer of Pesochnoye-1 and Lipovka-1 settlements on Lake Nero. Tverskoj Archeologichesky Sbornik 2013, 9, 345-360. (In Russian)

17. Alexandrovskiy, A.L.; Voronin, K.V.; Dolgikh, A.V.; Skripkin, V.V.; Glavatskaya, E.V.; Kovalukh, N.N. Radiocarbon age for the cultural layer of the Neolithic-Bronze Age settlement Pesochnoe-1 (Lake Nero, Russia). Radiocarbon 2012, 54, 589-597. [CrossRef]

18. Voronin, K.V. Complexes of the Bronze Age settlements Pesochnoye 1 and Dmitrievskaya Sloboda 2. Proc. II (XVIII) All Russ. Archaeol. Congr. 2011, 4, 37-40.

19. Alexandrovsky, A.L.; Alexandrovskaya, E.I. Evolution of Soils and Geographic Environment; Nauka: Moscow, Russia, 2005; p. 134. ISBN 5020339474. (In Russian)

20. Aleksandrovskii, A.L.; Aleksandrovskaya, E.I.; Dolgikh, A.V.; Zamotaev, I.V.; Kurbatova, A.N. Soils and Cultural Layers of Ancient Cities in the South of European Russia. Eurasian J. Soil Sci. 2015, 11, 1171-1181. [CrossRef]

21. Ivanova, T.; Pavlov, H.; Kerechanina, E. The analysis of the mineralization and transformation of organic substances, including sapropel. Analytica 2014, 19, 62-72. (In Russian)

22. Klucakova, M.; Pelikan, P.; Lapcik, L.; Lapcikova, B.; Jiri Kucerik, J.; Kalab, M. Structure and properties of humic and fulvic acids. I. Properties and reactivity of humic acids and fulvic acids. J. Polym. Mater. 2000, 17, 337-356.

23. Klucakova, M. Complexation of Copper (II) with Humic Acids Studied by Ultrasound Spectrometry. Org. Chem. 2012, 2012, 206025. [CrossRef]

24. Voronin, K. Implied reality-Indication of metal working at the Bronze Age settlements in the forest zone of Russia. In Proceedings of the Colloque International Anniversaire de l'APRAB, Bayeux, France, 19-22 June 2019; pp. 33-34.

25. Voronin, K.; Kabanova, M. Chemical-technological research and radiocarbon AMS dating of wall painting fragments from the ruins of the XIIth-XIIIth centuries AD church from archaeological excavations in the city of Smolensk, Russia. Herit. Sci. 2020, 8, 45. [CrossRef]

26. Oonk, S.; Slomp, C.P.; Huisman, D.J. Geochemistry as an Aid in Archaeological Prospection and Site Interpretation: Current Issues and Research Directions. Archaeol. Prospect. 2009, 16, 35-51. [CrossRef]

27. Carey, C.J.; Wickstead, H.J.; Juleff, G.; Anderson, J.C.; Barber, M.J. Geochemical survey and metalworking: Analysis of chemical residues derived from experimental non-ferrous metallurgical processes in a reconstructed roundhouse. J. Archaeol. Sci. 2014, 49, 383-397. [CrossRef] 
28. Golovanova, I.A.; Frolova, T.V. Influence of copper, zinc and cadmium on the carbohydrases activity of water invertebrate. Inland Water Biol. 2005, 4, 77-83. (In Russian)

29. Lobanova, T.A. Features of accumulation of metals by commercial fish species. Vestnik Kostromskogo Gosydarstvennjgo Yniversiteta Imeni Nekrasova Estestvoznanije 2008, 1, 18-21.

30. Rajkowska, M.; Protasowicki, M. Distribution of metals (Fe, Mn, Zn, Cu) in fish tissues in two lakes of different trophy in Northwestern Poland. Environ. Monit. Assess. 2013, 185, 3493-3502. [CrossRef]

31. Taylor Eighmy, T.; Kinner, A.E.; Shaw, E.L.; Dykstra Eusden, J.D., Jr.; Francis, C.A. Hydroxylapatite $\left(\mathrm{Ca}_{5}\left(\mathrm{PO}_{4}\right)_{3} \mathrm{OH}\right)$ Characterization by XPS: An Environmentally Important Secondary Mineral. Surf. Sci. Spectra 1999, 6, 193-201. [CrossRef]

(C) 2020 by the author. Licensee MDPI, Basel, Switzerland. This article is an open access article distributed under the terms and conditions of the Creative Commons Attribution (CC BY) license (http://creativecommons.org/licenses/by/4.0/). 